\title{
Adjective-Noun combinations in Romance and Greek of Southern Italy
}

\section{Polydefiniteness revisited}

\author{
Cristina Guardiano
}

Università di Modena e Reggio Emilia

cristina.guardiano@unimore.it

\author{
Melita Stavrou \\ Aristotle University Thessaloniki \\ staurou@lit.auth.gr
}

\begin{abstract}
This paper investigates aspects of adjectival modification in Romance and Greek of Southern Italy. In Italiot Greek, prenominal adjectives obey restrictions that do not exist in Standard Modern Greek, where all types of adjectives are allowed in prenominal position. As far as postnominal adjectives are concerned, in the textual tradition of Calabria Greek there is evidence of postnominal adjectives systematically articulated in definite nominal structures (henceforth DPs), in a structure similar to the so-called polydefinite construction that is typical of Standard Modern Greek (and of Greek in general since ancient times). Some residual evidence of such a construction is also found in Salento. Yet, in the varieties currently spoken in the two areas, postnominal adjectives are never articulated. The paper explores these patterns, with particular attention to the mechanisms potentially responsible for the loss of polydefiniteness.
\end{abstract}

\section{Keywords}

adjectival modification - polydefiniteness - predication - postnominal/prenominal adjectives - Salento Greek - Calabria Greek - Romance dialects of Southern Italy 
This study investigates aspects of adjectival modification in Italiot Greek. We focus on the dialects spoken in Grecia Salentina (henceforth Salento Greek) and Bovesìa (henceforth Calabria Greek), and compare them with Southern Italo-Romance and Standard Modern Greek.

Guardiano \& Stavrou (2014) have shown that in Italiot Greek, adjectival modifiers differ in at least two ways from Standard Modern Greek: (1) adjectives are predominantly postnominal (only a few are acceptable in prenominal position); (2) in Salento Greek, postnominal adjectives do not take their own article in definite DPs; some (written) varieties of Calabria Greek, instead, exhibit articulated postnominal adjectives: Guardiano \& Stavrou (2014) interpret them as a sign of high resistance to change (presumably due to the conditions of isolation of the Greek-speaking communities in Calabria).

In this article, we add to this picture a set of data collected from speakers of Calabria Greek, where there are no polydefinite structures with postnominal adjectives in definite DPS. This suggests that the written varieties explored by Guardiano \& Stavrou (2014) retain a pattern that was lost in more recent days, and presumably instantiate the "missing link" between the Greek system (as represented by Ancient Greek and Standard Modern Greek) and the new system observed in present day Italiot Greek, that is in turn identical to (Southern Italo-)Romance.

Our analysis is based on current assumptions about the syntax of adjectival modification in Standard Modern Greek. It has been claimed that, in Standard Modern Greek, direct modification adjectives, which are linearized prenominally, most likely originate prenominally (Cinque 2010, Alexiadou et al. 2007). In such a configuration, concord in phi-features, definiteness and case between the adjective and the noun is obtained through the Spec-Head relation (Giusti 2008, 2009, 2011). Guardiano \& Stavrou (2014) suggest that direct modification adjectives are generated prenominally in Italiot Greek, as well: their postnominal linearization, as in Romance, is due to the movement of the noun (or the noun phrase). A summary of the relevant data and their interpretation is provided in Section 3.

As far as adjectives linearized postnominally are concerned, Stavrou (2012, 2013; see also Alexiadou 2014) has proposed that in Standard Modern Greek they are instances of indirect modification and are merged postnominally, in a predicational/appositional structure that is presented in Section 4. In that configuration, agreement in phi-features, definiteness, and case between the adjective and the noun is obtained through the spell-out of a functional head (Pred), realized by an item that is homophonous with the definite article: this is the so-called "polydefinite construction", also described in Section 4. 
Here we argue that the need for a visible realization of Pred was lost in Italiot Greek as a consequence of a combination of factors: the development of noun (phrase) movement, the loss of case morphemes and of the need for visible agreement between the adjective and the noun, and the pressure of Romance. We develop our analysis in Section 5 .

Before presenting the relevant data and proposing our analysis, in Section 2 we provide some general information about the Romance- and Greek-speaking communities under investigation.

\section{Background notes: Romance and Greek in Southern Italy}

In Italy, Greek-speaking communities are found in Salento (various villages in the area of Lecce, called Grecìa Salentina) and Southern Calabria (various villages, now mostly abandoned, in the area of Reggio Calabria, called Bovesìa).

Their origins represent a controversial issue. ${ }^{1}$ As a matter of fact, the impact of the Greek substratum in Southern Italy has been massive (the area was Greek-speaking before the spread of Latin $)^{2}$ and has influenced the local Romance dialects in several respects. ${ }^{3}$ Additionally, as pointed out by Fanciullo (2001: 76), the relation of Salento and Calabria Greek to the original Greek element is unbalanced: "whereas Bovese (Calabrian Greek) is directly connected to the Greek of Graecia Magna ... Grico (Apulia Greek) could originate in the Hellenization of Southern Apulia during the (late) Roman empire".

According to recent sociolinguistic surveys, Greek in Italy nowadays is in regression; ${ }^{5}$ in particular, according to Martino (2009: 251), Greek in Bovesìa is "practically extinct". Especially in this area, most of the speakers are in fact

1 For the controversy about their origin, see at least Morosi (1870), Rohlfs (1924, 1933, 1972, 1980, 1985), Parlangeli (196o), Spano (1965), Falcone (1973), and Karanastasis (1974). For recent summaries, see Fanciullo (2001), Campolo (2002), Morgante (2004), Manolessou (2005), and Squillaci (2017).

2 Rohlfs (1972), Fanciullo (2001), among others.

3 As far as syntax is concerned, see Ledgeway (2013), Squillaci (2017), and references therein.

4 See, among the relevant literature, Comparetti (1866), Parlangeli (1960), Karanastasis (1974, 1984, 1992), Troiano (1982), Profili (1983, 1985, 1999), Katsoyannou \& Nucera (1986), Katsoyannou (1992a, 1992b, 1995, 1996, 1997, 1998, 1999a, 1999b, 2001), Morgante (2004), Manolessou (2005), and Ralli (2006).

5 Sobrero \& Romanello (1977), Gruppo di Lecce (1980), Miglietta \& Sobrero (2006, 2007), Romano \& Marra (2008), among others. For a recent survey of the current linguistic and sociolinguistic conditions of the Greek-speaking communities in Calabria, see also Squillaci (2017). 
"semi-speakers" (Dorian 1977). The consequence of this situation for our data collection was that sometimes our consultants were not able to provide unambiguous and trustworthy grammaticality judgments. Therefore, in order to support the data collected from the speakers, we gathered additional data from a selection of written records, which are likely to reflect the language spoken during the 19th and the first half of the 2oth century in the Greek villages where the Greek language was in active use. ${ }^{6}$ We noticed that, while in Salento the information collected from the speakers turned out to be consistent with that obtained from the textual sources, in Calabria several discrepancies emerged between traditional texts and the speakers, as is shown below.

As far as Romance is concerned, we considered three dialects belonging to the so-called Extreme Southern group ${ }^{7}$ (i.e., Salentino, ${ }^{8}$ Siciliano, ${ }^{9}$ and Southern Calabrese) ${ }^{10}$ and one belonging to the Lausberg area (Lausberg 1939), i.e. Northern Calabrese." No significant differences have been observed amongst these dialects as far as the phenomena under investigation are concerned; thus, here we treat them uniformly, under the label "Southern Italo-Romance".

Types of adjectival modification across Greek and Romance

\subsection{Direct vs. indirect modification adjectives}

The distinction between direct and indirect modification (by adjectives) goes back to Sproat \& Shih $(1988,1991)$. By using the term "direct modification", Sproat \& Shih refer to an adjective directly modifying the noun, without the

6 For Calabria Greek: Caracausi \& Rossi Taibi (1959), Falcone (1973), Crupi (1980), Condemi (1995), with additional evidence from Capialbi \& Bruzzano (1885), and Piromalli (1996). For Salento Greek: Pitrè (1872), Palumbo (1886, 1887, 1910, 1912, 1978), Mancini (1903), Mansi (1937), Aprile (1972), Aprile (1998), Cuomo (1977), Aprile et al. (1978), Aprile et al. (1980), Stomeo (1980), Montinaro (1994), Tommasi (1998), Sicuro (1999), and Orlando (2002).

$7 \quad$ Pellegrini (1977); see also, for more recent overviews of the classification of the dialects of Italy, Maiden \& Parry (1997), Loporcaro (2009).

8 Based on the native judgements of a speaker from Cellino San Marco (province of Brindisi, Salento).

9 Based on the native judgements of speakers from Ragusa, Mussomeli (province of Caltanissetta) and Aidone (province of Enna). The dialect spoken in Aidone is one of the residual Gallo-Italic dialects spoken in Sicily (Rohlfs 1966; Trovato 1981, 1989; Toso 2008). As far as the phenomena observed in the present analysis are concerned, this dialect does not exhibit any relevant difference with respect to the other varieties of Sicily considered.

10 Based on the judgements of a speaker from Reggio Calabria.

11 Based on the judgements of a speaker from Verbicaro (province of Cosenza). 
mediation of another constituent (i.e. a clause). In contrast, an adjective is assumed to indirectly modify the noun when it is contained within a (relative) clause.

This distinction was subsequently taken up by other linguists, especially those working in the cartographic framework, and was employed as a vehicle conveying two-originally unrelated though theoretically connectedconceptual oppositions: one is a syntactic opposition that concerns the placement of the adjective with respect to the noun (the pre-/postnominal opposition); the other represents the semantic opposition between attribution and predication (Bolinger 1967). Combining these distinctions was just a matter of time. Direct modification was correlated with the prenominal position of adjectives ("i.e. the use of the adjective as a noun modifier located within the boundaries of a nominal phrase"; Alexiadou et al. 2007: 291) and also with (semantic) attribution. Indirect modification was correlated with the postnominal position (the adjective as an indirect modifier originating within a relative clause) and, for obvious reasons, with predication ("the adjective heads an $\mathrm{A}[$ djective $] \mathrm{P}[$ hrase], which constitutes the predicate of the clause, taking the nominal phrase as its (external) subject"; Alexiadou et al. 2007: 290). Such associations were encouraged by the old transformational tradition of the 196os whereby the pre- and the postnominal position of adjectives was regularly connected via the combined effect of dedicated rules (Smith 1964).

The "derivational relationship between the two adjective positions" (Alexiadou et al. 2007:290) was initially addressed through two different approaches. According to the "reductionist" approach (see Alexiadou et al. 2007: 290-296), there exists only one underlying position (originally assumed to be postnominal: more precisely, all adjectives are assumed to originate within relative clauses and to be deep complements of the article), while the other is derived via movement: in the earlier proposals, the prenominal position is derived via leftward movement of the adjective from its originally postnominal position. However, it was soon realized that reducing all adjectives to the same source faced serious problems (Jackendoff 1977, among others, although most of those problems had been noticed already by Bolinger 1967). Thus, the 198 os witnessed an interesting twist: according to the "separationist" approach, different positions on the linear axis were associated with different underlying structures, and with different clusters of readings for the adjective. Thus, the class of adjectives was basically split: certain (sub-classes of) adjectives were assumed to be generated prenominally, while certain others postnominally (occasionally with overlaps).

The issue of adjective placement cannot be treated in detail here, as we focus on a specific phenomenon and its geographic distribution, i.e., the loss of poly- 
definiteness in the Greek varieties of Southern Italy. The reader is referred to Alexiadou et al. (2007) and Cinque (2010) for extensive discussion and relevant references.

What should be mentioned at this point, albeit briefly, is the very content of the terms "direct" and "indirect" modification. What seems to be a point of consensus today, even if the implementation of even common assumptions may differ, ${ }^{12}$ is that adjectives instantiating direct modification display the following semantic properties: they are enduring/individual-level, non-restrictive, modal, non-intersective, absolute, and specificity-inducing (Cinque 2010). In contrast, adjectives instantiating indirect modification encode the conceptually opposite readings: they are stage-level, restrictive, manner-denoting with an implicit relative clause reading, intersective, relative, and non-specificityinducing (Cinque 2010).

Especially in the cartographic approach, it has been assumed that these two opposing sets of interpretations are strictly connected to the position of the adjective with respect to the head noun: ${ }^{13}$ "if one and the same adjective shows up in both positions it is given two different interpretations, one for each position" (Alexiadou et al. 2007: 287).

12 See Bouchard (2002) and Cinque (2010) as the representatives of two different implementations of the old Bolingerian distinction (Bolinger 1967) between attribution (or reference modification) and predication (or referent modification).

13 In response to a criticism of one of the reviewers, it must be said that the (rather strict) correlation between interpretations and syntactic positions, which enjoys a rather dogmatic status in the cartographic approach, raises several doubts as regards the validityor the reality—of those different interpretations of the same adjective. Actually, there are several studies which show that the correlation in question is not strict and that many exceptions can be found (see, for instance, Cinque 2010 for a list of references). These questions should be taken seriously, but the present study is not the place to do it. Nonetheless, responding briefly to the reviewer, we can say first that we, as speakers of two of the languages that are discussed here, largely share the grammaticality judgements of the examples cited, although we acknowledge that the judgements in our case, as in so many other languages, are not black and white but occur in grey zones too. Second, the cartographic approach provides us with a solid ground as a theoretical tool for the analysis of our data. Finally, at least as far as the issue of intersectivity is concerned, an interesting observation is made by Bouchard (2002) who, in fact, argues that ALL adjectives are interpreted intersectively, and what makes a difference is what the adjective intersects with, i.e., whether the meaning of the adjective intersects with the whole reference of the noun or with subparts of it. The reader may also consult Abels \& Neeleman (2009) for an alternative account of the position and interpretation of adjectives. 
Here, we provide examples from Italian, a language that is typically used in the literature to illustrate these phenomena. ${ }^{14}$ For instance, the examples in (1) are often employed to show that, in Italian and Romance more generally, the prenominal position is strictly connected to direct modification. The most natural meanings for the prenominal adjectives in the sentences listed in (1) are indeed those associated with direct modification: enduring/individuallevel (1a), non-restrictive (1b), modal (1c), non-intersective (1d), absolute (1e), and specificity-inducing (1f) (Cinque 2010: 7-13).

(1) a. Le invisibili stelle di Andromeda esercitano un grande the invisible stars of Andromeda have a great fascino fascination

'Andromeda's stars, which are generally invisible, have a great fascination' (individual-level)

\# 'Andromeda's generally visible stars, which happen to be invisible now, have a great fascination' (stage-level)

b. le noiose lezioni di Ferri se le ricordano tutti the boring classes of Ferri SE them remember all 'everybody remembers Ferri's classes, all of which were boring' (nonrestrictive)

\# 'everybody remembers just those classes by Ferri that were boring' (restrictive)

c. Maria ha intervistato ogni possibile candidato Maria has interviewed every possible candidate 'Maria interviewed every potential candidate' (modal) \# 'Maria interviewed every candidate that it was possible for her to interview' (implicit relative clause reading)

d. un buon attaccante non farebbe mai una cosa delgenere a good forward not would-do never a thing of-the kind 'a forward good at playing forward would never do such a thing' (nonintersective) \# 'a good-hearted forward would never do such a thing' (intersective)

14 For further examples and more extensive discussion see, among many others, Alexiadou et al. (2007), Cinque (2010) and references therein. 
e. gli altissimi edifici di New York colpiscono tutti

the very-tall buildings of New York strike all

'New York's buildings, which are very tall objects, impress everybody' (absolute)

\#'New York's buildings, which are very tall compared to the average height of buildings, impress everybody' (relative)

f. domani alla festa so che interverrà un famoso tomorrow at-the party I-know that will-intervene a famous attore actor 'tomorrow, I know that a certain famous actor will come to the party' (specific)

\#'tomorrow, I know that some famous actor or other will come to the party' (nonspecific)

In contrast, the examples in (2) suggest that the postnominal position is compatible both with the interpretations associated with direct modification and with those associated with indirect modification: stage-level (2a), restrictive $(2 b)$, manner-denoting with an implicit relative clause reading (2c), intersective (1d), relative (2e), ans non-specificity inducing (2f) (Cinque 2010: 7-13).

(2) a. le stelle invisibili di Andromeda esercitano un grande

the stars invisible of Andromeda have a great fascino

fascination

'Andromeda's generally visible stars, which happen to be invisible now, have a great fascination' (stage-level)

Additional meaning available in this position: 'Andromeda's stars, which are generally invisible, have a great fascination' (individuallevel)

b. le lezioni noiose di Ferri se le ricordano tutti

the classes boring of Ferri SE them remember all 'everybody remembers just those classes by Ferri that were boring' (restrictive)

Additional meaning available in this position: 'everybody remembers Ferri's classes, all of which were boring' (non-restrictive) 
c. Maria ha intervistato ogni candidato possibile Maria has interviewed every candidate possible 'Maria interviewed every candidate that it was possible for her to interview' (implicit relative clause reading)

Additional meaning available in this position: 'Maria interviewed every potential candidate' (modal)

d. un attaccante buono non farebbe mai una cosa delgenere a forward good not would-do never a thing of-the kind 'a good-hearted forward would never do such a thing' (intersective) Additional meaning available in this position: 'a forward good at playing forward would never do such a thing' (non-intersective)

e. gli edifici altissimi di New York colpiscono tutti the buildings very-tall of New York strike all 'New York's buildings, which are very tall compared to the average height of buildings, impress everybody' (relative)

Additional meaning, available in this position: 'New York's buildings, which are very tall objects, impress everybody' (absolute)

f. domani alla festa so che interverrà un attore tomorrow at-the party I-know that will-intervene a actor famoso

famous

'tomorrow, I know that some famous actor or other will come to the party' (nonspecific)

Additional meaning, available in this position: 'tomorrow, I know that a certain famous actor will come to the party' (specific)

Moving next to English, where the rule is for the vast majority of adjectives to precede the noun, prenominal adjectives are ordered according to the semantic hierarchy first proposed by Sproat \& Shih (1991) and subsequently taken up by almost all researchers working in the field of adjectival modification..$^{15}$ Ordering restrictions affect both "the relative order of the adjectives" and "the relative distance of an adjective from the modified noun" (Alexiadou et al. 2007: 285): adjectives denoting more subjective properties are farther away from the noun than those denoting objective properties. An instantiation of

15 See the literature discussed in Scott (2002), Alexiadou et al. (2007), and Cinque (2010). 
such a hierarchy is presented in (3), from Alexiadou et al. (2007: 310), of which the English example in (4), from Alexiadou et al. (2007: 310) is a typical illustration.

(3) Quantification/Numeral $>$ Quality/Speaker-oriented $>$ Size $>$ Shape/Color $>$ Provenance/Argument

(4) the three beautiful big grey Persian cats

D quantification quality size color provenance $\mathrm{N}$

that I saw yesterday

Relative Clause

In English, as in Italian, and Romance more generally, prenominal adjectives are compatible with the interpretations connected with direct modification. For instance, the nominal phrase the visible stars in (5), from Cinque (2010: 6), has the individual-level reading, 'the stars that are generally visible'.

(5) the visible stars include Aldebaran and Sirius

Similarly, in (6), from Cinque (2010: 7-8), the non-restrictive meaning 'all his acts were condemned; they are unsuitable' is available.

(6) all his unsuitable acts were condemned

Example (7) shows a case of modal interpretation ('every potential candidate'):

(7) Mary interviewed every possible candidate. ${ }^{16}$

On the basis of the evidence provided by the ordering and interpretation of linearly prenominal adjectives, several researchers have proposed that direct modification adjectives are merged in "a set of functional projections which are hierarchically structured" (Alexiadou et al. 2007:311-312) and are originally prenominal. In particular, direct modification adjectives have been assumed to be merged either as specifiers of dedicated functional projections (Cinque 2010), or as syntactic heads (Abney 1987, Delsing 1993, Androutsopoulou 1995, among several others).

16 For further examples of the other readings mentioned above, see also Alexiadou et al. (2007). 
Notice that, in English, prenominal adjectives display interesting differences in their interpretation when compared to Romance: "prenominal adjectives, apart from the interpretation typically associated with the prenominal position, also take over the kind of interpretation that in the Romance languages is conveyed only by postnominal adjectives" (Alexiadou et al. 2007: 288). In particular, they are "systematically ambiguous between a reading in which they denote an enduring, or individual-level, property and a reading in which they denote a temporary, or stage-level, one" (Cinque 2010: 6). For instance, the nominal phrase the visible stars in example (5), besides the individual-level interpretation mentioned above ('the stars that are generally visible'), also has a stage-level interpretation ('the stars that happen to be visible now'). Similarly, the adjective unsuitable in (6) can be interpreted both as non-restrictive ('all his acts were condemned; they are unsuitable') and restrictive ('all and only his acts that were unsuitable were condemned'). Prenominal adjectives in English are also ambiguous between a modal ('every potential candidate' in (7)) and an implicit relative clause reading ('every candidate that was possible for her to interview'). These ambiguities arise for nearly all types of readings shown in (1) and (2) (see, for detailed examples and further literature, Alexiadou et al. 2007: 289-394, and Cinque 2010: 1-17). Larson (1998, 2000a, 20oob; see also the examples discussed in Cinque 2010:19-20) has shown that direct and indirect modification adjectives actually can co-occur in prenominal position in English, and that the adjectives interpreted as direct modifiers are always closest to the noun (namely, "the adjectives displaying the interpretive properties of indirect modification precede [...] those displaying the properties of direct modification", Cinque 2010: 57): for instance, in the nominal phrase in they described every (in)visible visible star (Cinque 2010: 57, example 1b), the first adjective in the linear string ('(in)visible') can only be interpreted as stage-level ('the stars which are (in)visible now'), while the second ('visible') can be interpreted as individual-level ('the stars which are usually visible').

In order to account for these facts, it has been claimed that adjectives interpreted as indirect modifiers originate in a dedicated source that is often referred to as a predicative-like structure (a reduced relative clause according to Kayne 1994, Alexiadou 2001, Alexiadou \& Wilder 1998; or a small clause, Demonte 1999). In particular, Cinque (2010) assumes that prenominal indirect modification adjectives in English are merged in a reduced relative clause that is higher than the projections where direct modifiers are merged (for a representation and discussion of the structure he proposes, see Cinque 2010: 63, example 14).

On the other hand, the ambiguities exhibited by postnominal adjectives in Romance have been explained assuming that in those languages the adjectives 
which appear linearized after the noun have two sources. One is the genuinely prenominal projection where direct modifiers are merged, the other is (probably) a postnominal projection where indirect modifiers are assumed to be merged (these are described in Section 3.3). The pre-/postnominal position on the syntagmatic axis of the adjectives structurally generated in prenominal position has been assumed to be contingent on the movement of the head noun or of the lexical projection Noun Phrase (NP; see Grosu 1988; Valois 1991a, 1991b; Bernstein 1991, 1993; Crisma 1991, 1996; Cinque 1994, 1999, 2005a, 2010; Giusti 1993, 2002; and Longobardi 1994, among others); NP-movement may also be supplemented by remnant movement (Shlonsky 2004 and Laenzlinger 2005, among others). Here, we are agnostic as to the N/NP-movement issue, and broadly refer to movement across prenominally merged adjectives by the term "N/NP-movement". That is because our point of focus is orthogonal to the specific debate, and the patterns we are interested in can, in principle, be derived under any of the two implementations of nominal movement.

\subsection{Direct and indirect modification adjectives in Greek}

In Standard Modern Greek, every adjective or adjective type can occur to the left of the noun ("in Greek all adjectives are prenominal", Alexiadou et al. 2007: 364): the prenominal position is the default position for adnominal adjectives. As in English, prenominal adjectives are usually ordered according to the hierarchy in (3), as shown in (8). ${ }^{17}$

$$
\begin{array}{lllll}
\text { poles } & \text { omorfes megales } & \text { aspres } & \text { persikes } & \text { gates }^{18} \\
\text { many } & \text { beautiful big } & \text { white } & \text { Persian cats } \\
\text { quantification quality size color } & \text { provenance N } \\
\text { 'many beautiful big white Persian cats' } & &
\end{array}
$$

As far as their interpretation is concerned, prenominal adjectives, like in English, are ambiguous between the individual-level, non-restrictive, modal, non-intersective, absolute, intensional, and specificity-inducing interpretation

17 In Greek, this pattern is also found in the most ancient varieties of the language, and seems to be genealogically stable (Guardiano 2003, Bernasconi 2011, Guardiano \& Stavrou 2014).

18 The ordering megàles òmorfes is also possible, though less common. It is worth mentioning that, precisely as in English (see Cinque 2010 for a summary and discussion), permutability among adjectives is sometimes possible if a change in scope or focus is intended. 
typical of direct modification adjectives, and the stage-level, restrictive, manner-denoting, intersective, and extensional interpretation typical of indirect modification adjectives (Alexiadou et al. 2007, Stavrou 2012). For instance, the adjective palia in (9), from Kolliakou (2004), when prenominal, is ambiguous between the intersective ('in bad condition, ruined') and the non-intersective reading ('a building that used to serve as a church in the past').

(9) a. mia palia eklisia

an old church

i. 'a church in bad condition' (ruined, etc.)

ii. 'a former church'

b. $i$ palia eklisia

the old church

i. 'the church in bad condition' (ruined, etc.)

ii. 'the former church'

Thus, in Standard Modern Greek, prenominal adjectives display the same type of ambiguities seen in English (Section 3.1): they can be interpreted as either indirect or direct modifiers and, when co-occurring, the adjectives interpreted as direct modifiers are always closer to the noun than those displaying the interpretive properties of indirect modifiers (in ta aorata orata asteria, lit. 'the invisible visible stars', the first adjective, aorata, can only be interpreted as stage-level — 'the stars which are not visible right now' — while the second adjective, orata, can only be interpreted as individual-level-'the stars which are normally visible'). Thus, precisely as in English, we assume two distinct merge positions for prenominal modifiers: direct modification adjectives are merged as specifiers of dedicated functional projections higher than the noun, and indirect modification adjectives are merged as reduced relative clauses in a higher position, but lower than NumP: DP $>$ NumP $>$ Reduced RC $>$ AP $>N$ P . No such position is crossed over by the N/NP; thus, both the adjectives generated as direct modifiers and those generated as (prenominal) reduced relative clauses are linearized prenominally.

A difference with respect to English is that, in Standard Modern Greek, many (though not all) adjectives can also appear postnominally. Unlike prenominal ones, postnominal adjectives can only be interpreted restrictively, intersectively and as stage-level predicates (Kolliakou 2004, Campos \& Stavrou 2004, Alexiadou et al. 2007, Stavrou 2012). For instance, as shown in (10), from Kolliakou (2004), the adjective palia can only have the intersective interpretation 'in bad condition'. 
(10) mia eklisia palia
a church old
i. *'a former church'
ii. 'a church in bad condition' (ruined, etc.)

In definite DPs, postnominal adjectives must be preceded by a definite article which "doubles" the definite article that precedes the noun (11a); definite DP s containing a postnominal (modifying) adjective without an article are ungrammatical, as shown in (11b).

(11) a. to pedi to kalo the child the good 'the good child'

\section{b. ${ }^{*}$ to pedi kalo the child good}

The phenomenon in (11a) was called "determiner (or definiteness) spreading" by Androutsopoulou (1995), and the noun phrase where articulated adjectives appear is dubbed "polydefinite". ${ }^{19}$ The phenomenon is typical of everyday, colloquial language; it is not attested in most written, learned, or scientific genres, where the prenominal positioning of adjectives seems to be the rule. Concerning this fact, an anonymous reviewer expresses doubts as to the correctness of our method insofar as we compare a construction that is mostly a feature of oral speech in Standard Greek with the same construction that appears (only) in written texts in Calabria Greek. The objection is quite reasonable, and gives us the opportunity to make two further observations. First of all, the written texts of Calabria Greek explored here are actually transfers of various types of unofficial texts originating in the oral tradition and are, therefore, likely to encode everyday informal language rather than literary styles. Second, the polydefinite construction, although typical of the oral language, is not entirely absent from written usage, and this holds true throughout the history of Greek (Manolessou 2000; Guardiano 2003, 2016), at least ever since a definite article in $\mathrm{D}$ (eterminer position) developed: indeed, "the presence of determiners within the noun phrase realizing $\mathrm{D}$ is a prerequisite for the presence of the multiple pattern" (Alexiadou 2014: 4). One further remark is that there is one

19 Kolliakou (1999, 2004), Campos \& Stavrou (2004), Alexiadou et al. (2007), Alexiadou (2014). 
particular subtype of the polydefinite construction, exemplified in (14) below, which is not encountered in typical written styles. This is the order [art Adj

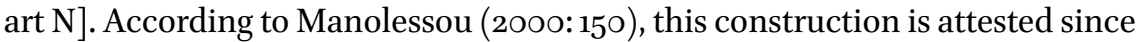
Medieval Greek, but only in non-literary styles ("in more literary verse texts [... it] is either non-existent or rare, while in more popular texts it is much more frequent", Manolessou 2000: 150). As shown further below, this construction has been analyzed as generated through fronting of the constituent [art+Adj], originally generated postnominally, to the left of $\mathrm{D}$, and such a movement is usually associated with some type of informational markedness (e.g., focus). Thus, it is not surprising that it is absent from written texts (or very rare), where discourse markedness strategies are normally not employed. We say more about this particular order below.

The analyses that have been proposed for polydefiniteness are many and different, and placed within different linguistic persuasions. Here we cannot do justice to all of them-let alone attempt a survey-but we can at least classify them according to what we understand are the major differences in the way(s) they approach the phenomenon. There are those that are launched by and large within the cartographic approach (which echoes Kayne's 1994 antisymmetric theory), dating back to the 199os, as depicted in work by Androutsopoulou (1995), and continuing today (cf. Ntelitheos 2003, Panayidou 2013, Velegrakis 2011); within the same framework are found those that favor some type of clausal analysis (Alexiadou \& Wilder 1998, Campos \& Stavrou 2004, Marinis \& Panagiotidis 2011). The latter can be further distinguished according to whether the clause in which the adjective of the polydefinite originates is a kind of reduced relative (ComplementPhrase/IinflectionPhrase (CP/IP), in the spirit of Kayne 1994), or whether it is a kind of small clause (Stavrou 2012) or appositional structure (Lekakou \& Szendroi 2012).${ }^{20}$ Outside the generative framework, Kolliakou (2004), launched within Head-Driven Phrase Structure Grammar (HPSG), is a deep and thorough semantic and syntactic analysis of polydefiniteness, and a valuable reference work.

The adjectives in polydefinite DP s can only be interpreted restrictively, intersectively, and as stage-level predicates (Kolliakou 2004, Campos \& Stavrou 2004, Alexiadou et al. 2007, Leu 2008, Stavrou 2012, Lekakou \& Szendroi 2012, Alexiadou 2014, Lekakou 2017). In (12a), from Kolliakou (2004), for instance, the sentence with the articulated adjective $i k a n i$ in postnominal position has the

20 Grohmann \& Panagiotidis (2004), on the other hand, argue that the postnominal position is due to the movement of the noun to a higher position and the definite article that precedes the adjective is an effect of such a movement (an anti-locality effect). 
meaning 'only the efficient researchers will be fired'. If the adjective is prenominal and does not have an article, as in (12b), the sentence is ambiguous: it can mean (i) 'all the researchers, including the efficient ones, will be fired' (nonrestrictive interpretation of the adjective), and (ii) 'those researchers that are efficient will be fired', as in (12a), with the adjective interpreted restrictively.

(12) a. o dhiefthindis dhilose oti $i$ erevnites $i$ ikani tha the director declared that the researchers the efficient will apolithun

fired

'the director declared that (only) the efficient researchers will be fired'

b. $o$ dhiefthindis dhilose oti $i$ ikani erevnites tha the director declared that the efficient researchers will apolithun

fired

i. 'the director declared that all the researchers, including the efficient ones, will be fired'

ii. 'the director declared that those researchers that are efficient will be fired'

Example (13), again from (Kolliakou 2004), is identical to (10), with the only difference being that in (13) the DP is definite. As in (10), the adjective palia, in postnominal position, is only interpreted intersectively ('in bad condition, old building').
(13) $i$ eklisia $i$ palia
the church the old
i. * 'the former church'
ii. 'the church in bad condition' (ruined, old, etc.)

To sum up, it seems that in Greek all postnominal adjectives can only get the kind of interpretation typical of indirect modification.

There is one more aspect associated with the use of polydefinitetenss and that is the pragmatic impact it has in discourse. As has been shown in detail by Kolliakou (2004; also by Cornilescu 2006 and Cornilescu \& Nicolae 2011 for the Romanian [cel+Adj] construction) the postnominal adjective-which is, as mentioned above, emphatic and/or contrastive - serves as a means to pick out a salient property (according to Kolliakou 2004, the unique property) of the referent, thus narrowing down the set of referents which have been previously 
introduced in the discourse. Concerning these aspects, at least since Anagnostopoulou (1994; see also Tsakali 2008), some parallelism with the interpretation of clitic doubling structures has been pointed out. In particular, it has been suggested that the two share some strict "familiarity" condition (see also Campos \& Stavrou 2004). Since the interrelationship between the semantics and the pragmatics of polydefiniteness merits deeper research, here we are simply assuming that the pragmatic impact of the construction is rendered possible because the postnominal adjective, being an intersective modifier, modifies the whole network of meaning components of the noun, which make up its referent, as a complete entity (Bouchard 2002).

As mentioned above, in Standard Modern Greek, polydefinite adjectives can also appear in prenominal (in fact, pre-article) position, to the left of the article that precedes the noun, as shown in (14).

\section{(14) to kalo to pedi the good the child 'the good child'}

The order to kalo to pedi (14) has been described as a consequence of a fronting movement of the complex [art+AP] to the left of D-either to SpecDP or to the specifier of a dedicated projection above DP (Horrocks \& Stavrou 1987, Stavrou \& Horrocks 1989, Campos \& Stavrou 2004, Guardiano \& Stavrou 2014, Guardiano \& Michelioudakis 2019, among others). This movement is triggered by the feature [+contrast] (or [+focus], or both) with which the articulated adjective is endowed. However, as assumed by Campos \& Stavrou (2004), the adjective may stay in situ and bear contrastive stress, or move higher. In any case, the fact remains that the adjective in the polydefinite DP receives emphatic pitch accent and is also pragmatically focal because it stands for the new information conveyed by the entire nominal phrase, whereas the denotation of the noun represents old or background knowledge. ${ }^{21}$ As

21 An anonymous reviewer remarks that the presence of Focus (movement) inside the DP has been disputed on the grounds that Focus is a propositional projection (this issue is discussed also by Lekakou \& Szendroi 2012). It is true that Focus (and Topic) inside the DP will always be overridden by the sentential focus/topic, but this does not eliminate the possibility of having a focal constituent within the DP. In fact, the assumption of having a left periphery in the DP constitutes a central part of the analysis of a number of studies of polydefiniteness and not only for Greek (cf. Ntelitheos 2004; Campos \& Stavrou 2004; Giusti 2005, 2006; and Cornilescu \& Nicolae 2011, among others). The interaction between focus and topic inside the DP and their sentential homologues constitutes the theme of separate studies and will not be addressed here. 
mentioned above, structures like (14) are not found in Ancient Greek (Manolessou 2000, Guardiano 2003).

With all the above being said, an assumption made by several authors (for instance Alexiadou \& Wilder 1998; Alexiadou et al. 2007; Stavrou 2012, 2013; Alexiadou 2014) on the basis of the aforementioned evidence is that Standard Modern Greek has originally postnominal adjectives, which are assumed to be generated in a clausal-like structure. Based on that assumption, Stavrou (2012, 2013) argues that the set of interpretations that articulated adjectives receive in polydefinite structures are due to their function as indirect modifiers rather than to the presence of the definite article. If this is on the right track, it follows that in the polydefinite construction the definite article in front of the adjective must be assigned a purely formal role: it can be dubbed the "spurious" article along the lines of den Dikken (2006). In particular, according to Stavrou (2012, 2013), the definite morpheme that accompanies the adjective in the polydefinite DP is attributed to the need of the postnominal adjective to show concord with the noun it modifies and which it linearly follows. Although for clarity we continue to refer to the item that precedes the adjective as "(definite) article", it is important to realize that we do not really consider that item an article per se but rather a morpheme homophonous to the article which plays a special role in polydefiniteness (realization of definiteness and case), as well as in nominal appositive structures more generally. This line of reasoning is in line with those analyses that assign an expletive (functional) character to the adjectival article in polydefinite DP s (cf. Androutsopoulou 1995), while attributing definiteness to either a postulated DefinitenessPhrase, DefP (Lekakou \& Szendroi 2012), or a dedicated Iota Phrase (Kyriakaki 2011); for a more general crosslinguistic perspective concerning the role and function of (different types of) similar morphemes, which appear with noun modifiers in various languages and share several properties with the adjectival article in Greek (i.e., Linkers), see Franco, Manzini \& Savoia (2015) and Manzini \& Savoia (2018). Our analysis of the structure proposed for Greek polydefiniteness is developed in Section 4.

To sum up the content of the present section, in Standard Modern Greek there seems to be evidence of three distinct separate sources for adjectival modifiers: a prenominal merge position for direct modification adjectives and two distinct positions where indirect modification adjectives are generated, one prenominal, of the type advocated in Cinque (2010) for English, and one postnominal, which is the topic of discussion in Section 4.

\subsection{Direct and indirect modification adjectives in Romance}

In Romance, as has been shown in (1), prenominal adjectives are unambiguously interpreted as direct modifiers, namely as being modal/subjective, inten- 
sional, non-restrictive, and non-intersective, and functioning as individual level predicates. All these interpretations are also available to postnominal adjectives, which, as shown in (2), are ambiguous between the direct modification interpretation and its conceptual opposites (manner denoting, extensional, restrictive, intersective, stage level; cf. Cinque 2010 and Alexiadou et al. 2007 for a summary and the relevant literature). These ambiguities have been explained as follows.

As far as adjectives linearized postnominally but interpreted as direct modifiers are concerned, it has been assumed ${ }^{22}$ that they merge in prenominal position, and that their postnominal occurrence is a consequence of $\mathrm{N} / \mathrm{NP}-$ movement. The landing site selected in each language determines which class(es) of such prenominally merged adjectives will appear pre- or postnominally. Romance languages instantiate various possibilities of such raising (Guardiano et al. 2018). Bernstein (1991), for instance, has shown that in Walloon, provenance adjectives cannot be prenominal (15), and has assumed that this depends on the fact that N/NP systematically raises over them.

(15) a. one bèle bleuve cote alemande

a beautiful blue dress German

'a beautiful blue German dress'

b. * one bèle bleuve alemande cote

In Italian (and, as a matter of fact, in Spanish, French, Portuguese, Romanian, and several other Romance languages $)^{23}$ the N/NP moves higher: as shown in (16), provenance and (shape/)color adjectives are never found in prenominal position.

(16) a. un grande vaso rotondo/rosso cinese a big vase rounded/red Chinese 'a big rounded/red Chinese vase'

b. * un rotondo/rosso vaso cinese

c. * un cinese vaso

22 Bernstein (1991, 1993), Crisma (1991, 1996), Cinque (1994, 2005a, 2010), Longobardi (2001), Laenzlinger (2005), among others.

23 Guardiano et al. (2016), Guardiano et al. (2018). 
In Romance, some adjectives can occur in both pre- and postnominal position. As a rule, each position is associated with a different set of interpretations or meanings. For instance, in example (17), adapted from Alexiadou et al. (2007: 344-345), prenominal occurrence of povero as in (17a) is associated with the meaning 'pitiable' rather than 'poor, impoverished', and indeed is compatible with the adjective ricco ('rich'); on the contrary, its postnominal occurrence in (17b) can only be associated with the meaning 'poor, impoverished', and it is therefore incompatible with its opposite, 'rich'.

(17) a. quel povero ragazzo (ricco) non ha amici that poor boy rich not has friends 'that poor/pitiable (rich) guy doesn't have friends'

b. quel ragazzo povero *ricco non ha amici that boy poor rich not has friends 'that poor/impoverished guy doesn't have friends'

Similarly, in (18), adapted from Bouchard (2002), the adjective nuova in prenominal position in (18a) has the interpretation 'one more, an additional' (the addition of the adjective usata 'used' is indeed possible), while in postnominal position the interpretation can only be 'new', as shown by the ungrammaticality of the adjective usata 'used' in (18b).

(18) a. ho comprato una nuova macchina (usata) have bought a new car used 'I bought one more (used) car'

b. ho comprato una macchina nuova *usata have bought a new car used 'I bought a (brand) new car'

A further, quite similar, case is provided by example (19), where vecchio in prenominal position, as in (19a), has the meaning 'we have been friends for a long time', while in postnominal position it can only have the meaning 'aged', as in $(19 b)$.

(19) a. ho incontrato un vecchio amico have met a old friend 'I met an old friend' 


\section{b. ho incontrato un amico vecchio \\ have met a friend old \\ 'I met an old/aged friend'}

The adjective sola in (20) shows a further case: in prenominal position as in (20a) it means 'only one', while in postnominal position as in (2ob) it can also have the meaning 'alone'.

(20) a. è arrivata una sola ragazza

is arrived a only girl

'only one girl has arrived'

\section{b. è arrivata una ragazza sola}

is arrived a girl alone/only

'only one girl has arrived', 'A girl has arrived alone'

Example (21) (Alexiadou et al. 2007: 345, example 84, adapted from Bouchard 2002) shows a further instance of an adjective that has two different meanings according to its pre-/postnominal occurrence: the first occurrence of numerose, in prenominal position, is associated with a numeral reading ('many families'), while the second occurrence, in postnominal position, has a modal reading ('families with many components').

(21) numerose famiglie numerose hanno protestato numerous families numerous have protested 'many numerous families have protested'

To explain these cases, it has been suggested (see, for instance, Bernstein 1993; Larson 1999; 2000a, 20oob; Crisma 1996, among others) that these adjectives (along with a few others) actually merge in two different (prenominal) positions. For instance, the prenominal occurrence of povero in (17a) is likely to be generated in the projection where speaker-oriented adjectives are merged, while the postnominal povero in $(17 \mathrm{~b})$ is presumably generated in a position closer to the noun (where adjectives expressing more or less objective properties of $\mathrm{N}$ are merged): as such, it has been crossed over by N/NP and therefore it occurs postnominally. Similarly, the first occurrence of numerose in (21) is likely to be generated in a high projection where quantification items are merged, while its second occurrence is likely to be generated in a lower position, closer to N, where qualifying/size adjectives are merged (Alexiadou et al. 2007). 
In the Romance dialects of Southern Italy (Guardiano 2014, Guardiano \& Stavrou 2014, Guardiano et al. 2016, Guardiano et al. 2018), only a few quantificational and quality-denoting, speaker-oriented adjectives are found in prenominal position as in (22); all the others occur, without exception, in postnominal position as in (23).

(22) na bbeda makina

a beautiful car

'a beautiful car'

(23) a. na makina ranni bblu teteska

[Siciliano]

a car big blue German

'a big blue German car'

b. * na ranni makina

c. * na bblu makina

d. * na teteska makina

Notice that, unlike Italian, these dialects disallow multiple prenominal modification; when two (or more) adjectives modify one and the same noun, only one can be prenominal. This suggests that in Southern Italo-Romance only one prenominal position is available for (a few, lexically specified) adjectival modifiers. Similar patterns have been spotted in other Italo-Romance dialects. ${ }^{24}$

Cross-linguistically, this is not an exceptional case: there are, in fact, languages in which most, if not all, prenominal adjectives occur postnominally as a consequence of N/NP-movement. In Irish, for instance, all adjectives (with few exceptions) only occur in postnominal position: this has been analyzed as a consequence of " $\mathrm{N}$ raising around the adjectives to a functional head position in the space between D and N" (McCloskey 2004: 1; cf. also Rouveret 1994 for Welsh). Similarly, in Semitic (see Shlonsky 2004, Cinque 2005b), the postnominal position of adjectives, as well as their mirror-image ordering, has been explained as the consequence of NP-movement combined with rollup.

In Southern Italo-Romance, the adjectives which occur in prenominal position are also found postnominally. In this case, the differences in their interpre-

24 Ledgeway (2007), Guardiano et al. (2016). 
tation are very similar to those observed in (17)-(21). To mention one example, in (24) and (25), from Salentino Romance, ${ }^{25}$ the adjective bwenu ('good') in postnominal position, as in (24a, 25a), has the modal meaning 'good, of good quality, edible', while in prenominal position, as in $(24 \mathrm{~b}, 25 \mathrm{~b})$, it can only get the quantificational interpretation, 'a big quantity of', an interpretation that is excluded when the adjective is postnominal.

(24) a. ogghju (ku) mbiu mjeru bbwenu

[Salentino]

want.I that drink.I wine good

'I want to drink good wine'

b. ogghju (ku) mbiu bbwenu mjeru

want.I that drink.I good wine

'I want to drink a big quantity of wine'

(25) a. a kkweti fungi bbweni

has picked mushrooms good

'He/she picked good/edible mushrooms'

b. a kkweti bbweni fungi

has picked good mushrooms

'He/she picked a big quantity of mushrooms'

To explain the pre- and postnominal occurrence of bbwenu in (24) and (25), one could resort to the same explanation suggested for the meaning alternations observed with povero, nuovo, vecchio, solo, and numeroso in (17), (18), (19), (20), and (21), respectively, namely that the adjective has two prenominal sources: one higher, where it gets the meaning 'a good quantity of' and one lower, where it gets the meaning 'of good quality'.

An adjective that displays alternations in interpretation which seem to be connected to its position is bellu, beddu. ${ }^{26}$ In Siciliano, the prenominal position

25 We are grateful to Franco Fanciullo (personal communication) for the Salentino Romance data.

26 The interpretations of this adjective in French are discussed by Bouchard (2002). He observes that with some nouns this adjective can only intersect with the core meaning ('characteristic function') of the noun. For instance, the meaning of a nominal expression like un beau couteau can only be ' $\mathrm{X}$ is good as a knife'. Un couteau beau ('an attractive knife') is reported as infelicitous (\#) by the author. So, in his terms, beau is intersective even prenominally, but what it intersects with is the very essence of 'being a knife'. 
can only be associated with the meaning ' $\mathrm{X}$ has everything in order to be an excellent X'. For example, in (26a), bbella/beda ${ }^{27}$ kassata has the meaning 'a cassata that has all the properties required to be a good cassata'. In postnominal position, as in (26b), an additional interpretation is possible, namely the one associated with the meaning 'aesthetically pleasant'. Similar alternations are also shown in (27).

(26) a. mi vwogghju mancjari na bbella kassata

[Siciliano]

to.me want.I eat.I a beautiful cassata

'I want to eat a well made cassata'

b. mi vwogghju mancjari na kassata bbella

to.me want.I eat.I a cassata beautiful

'I want to eat a beautiful cassata', 'I want to eat a well made cassata'

(27) a. Gjovanni s' akkattau na bbella kasa/makina

Giovanni to.him bought a beautiful house/car

'Giovanni bought a house/car that has everything in order (to be a good house/car)'

b. Gjovanni s' akkattau na kasa/makina bbella

Giovanni to.him bought a house/car beautiful

'Giovanni bought a beautiful house/car', 'Giovanni bought a house/car that has everything in order (to be a good house/car)'

Examples (28)-(30) are from Salentino.

(28) a. na bbella piccinna

[Salentino]

a beautiful girl

'A girl who is well behaved, pleasant, nice to talk with ...'

b. na piccinna bbella

a girl beautiful

'A nice girl'

27 In the varieties of Sicily explored here we have not found any relation between the phonetic forms of this adjective and its position or interpretation: the forms bellu and bed $(d) u$ alternate freely. 
(29) a. na bbella makina

a beautiful car

'A car that is well equipped, easy to drive, beautiful ...'

b. na makina bbella

a car beautiful

'A beautiful car'

(30) a. na bbella kasa

a beautiful house

'A house that is comfortable, spacious ...'

b. na kasa bbella

a house beautiful

'A beautiful house'

Finally, in these dialects the postnominal position is associated with the interpretation of indirect modifiers (which is never available with prenominal adjectives). For instance, the adjective ranni in (31a) is compatible with a restrictive interpretation, and the adjective socjalista in (31b) can be interpreted as non-specificity inducing. Notice that the postnominal position is also compatible with the conceptually opposite meanings, as shown in the translations of the examples in (31), both from Siciliano.

(31) a. $i$ figghi ranni ri Ggjovanni su ddittura

[Siciliano] the sons big of Giovanni are doctors 'the older sons of Gianni are doctors' (restrictive) Additional meaning available in this position: 'Gianni's sons, who are aged, are doctors' (non-restrictive)

b. rumani o komiziu veni nu sinniku socjalista tomorrow at-the meeting comes a major socialist 'tomorrow, some socialist major will intervene at the meeting' (nonspecific)

Additional meaning, available in this position: 'tomorrow, a certain socialist major will intervene at the meeting' (specific)

On the basis of the aforementioned evidence, Guardiano \& Stavrou (2014) assume that, as in the rest of Romance, in these dialects adjectives have two sources. The first is the source where direct modifiers are merged: a set of 
originally prenominal positions which are hierarchically ordered. In Southern Italo-Romance, like in Celtic, such positions are massively crossed over by the N/NP; thus, most direct modification adjectives are found postnominally. Only adjectives with quantitative interpretation (like bwenu in 24 and 25) and speaker-oriented ones (like bellu/bedu in $26-30$ ) are allowed in prenominal position. The second source is the one where indirect modification adjectives linearized postnominally are assumed to be merged (see the discussion about Romance in Section 3.1). This would explain the ambiguities in the interpretation of postnominal adjectives (which are similar to the rest of Romance), the differences in scope associated with different word orders of postnominal adjectives, and the (actually marginal) occurrence of postnominal adjectives after prepositional modifiers.

\subsection{The positioning of adjectives in Italiot Greek}

As already noted in Guardiano \& Stavrou (2014), Italiot Greek exhibits at least two major differences with respect to Standard Modern Greek in the syntax of adjectival modifiers. The first is that there are strong constraints on prenominal adjectives. In Salento Greek, as in Southern Italo-Romance, almost all classes of adjectives are disallowed in prenominal position, as shown in $(32)$.

(32) a.i. meletisa ena libbro griko

[Salento Greek] read.ıPST a book Greek 'I read a Greek book'

a.ii. *meletisa ena griko libbro

b.i. melètisa èna libbro ròdino read.1Pst a book red 'I read a red book'

b.ii. * meletisa ena rodino libbro

c.i. meletisa ena libbro cinurio read.ıPST a book new 'I read a new book'

c.ii. * meletisa ena cinurio libbro 


\section{d.i. meletisa ena ïbbro mea read.IPST a book big 'I read a big book'}

d.ii. ?? meletisa ena mea libbro

Indeed, there are very few exceptions to this pattern. It appears that only numerals, the modifiers 'other' and 'only' and the adjective orrio ('nice', 'beautiful', along with a few other synonyms or antonyms, with strong speakeroriented interpretation) are accepted in prenominal position (33). ${ }^{28}$ In fact, in Salento Greek, postnominal modification seems to be the default choice for most adjectives, as in Southern Italo-Romance (and unlike Standard Greek).

(33) meletisa ena orrio libbro read.1PST a beautiful book

[Salento Greek]

'I read a beautiful/interesting book'

On the basis of this evidence, Guardiano \& Stavrou (2014) assume that the restrictions observed on prenominal adjectives are triggered by the same rule as Southern Italo-Romance, namely N/N P movement over (almost) all prenominally merged adjectives.

In the written sources of Calabria Greek (34), the number of prenominal adjectives is extremely small (Guardiano \& Stavrou 2014): almost all (classes of) adjectives occur systematically in postnominal position.

(34) a. ena provaton galari

[Calabria Greek—written sources] a sheep dairy 'a dairy sheep' [ena galari provaton $>$ unattested]

b. ena hhorafi herco

a field fallow

'a fallow field' [ena herco hhorafi > unattested]

c. tin ffacin din aspri

the lentil the white

'the white lentil' [tin aspri ffacin > unattested]

28 Note that adjectives like orrio, which are accepted in prenominal position, are also accepted in postnominal position, with differences in their interpretation similar to those seen above in Romance with beddu/bellu. 
d. mia frafti megali

a hedge big

'a big hedge' [mia megali frafti > unattested]

The adjective maño (with the subject-oriented meaning 'beautiful', 'nice') is found in prenominal position (35), as are, more marginally, kalo ('good') and brutto ('bad').

(35) $\mathrm{mu}$ irte mia mañi micedda to.me came a beautiful young.lady

[Calabria Greek—written sources]

'a beautiful young lady came to me'

Two other adjectives which are found in prenominal position are mavro, as in (36a), and povero, as in (37a) (the latter borrowed from Romance). Notably, both such adjectives exhibit significant differences in their interpretation according to whether they occur prenominally or postnominally; such differences are identical to those observed in Romance (see (17)): in prenominal position they take a strongly speaker-oriented interpretation ('miserable, pitiable'), while in postnominal position as in $(36 \mathrm{~b})$ and $(37 \mathrm{~b})$ they take the interpretation 'black' and 'poor, impoverished', respectively. These interpretations have been confirmed by the speakers.

(36) a. ena mavro sciddi

a black dog

[Calabria Greek—written sources]

'a pitiable/miserable dog'

b. ena sciddi mavro
a dog black
'a black dog'

(37) a. o povero liko

the poor wolf

'the pitiable wolf'

b. to lleddendu tom bovero

the brother the poor

'the poor (= who is not rich) brother' 
As far as the currently spoken varieties of Calabria Greek are concerned, the speakers provided judgements which are consistent with the distribution we encountered in the texts: provenance, color and shape adjectives are never possible in prenominal position, as shown in (38).

(38) a.i. mia micedda vutana

[Calabria Greek—spoken]

a girl bovese

'a girl from bova'

a.ii. * mia vutana micedda

b.i. ena vivlio rodino

a book red

'a red book'

b.ii. * ena rodino vivlio

c.i. mia gastra strogghilo

a vase rounded

'a rounded vase'

c.ii. * mia strogghilo gastra

Marginally tolerated in prenominal position are some size- and qualitydenoting adjectives. For instance, the adjective megàlo, never found prenominally in the texts, is accepted in prenominal position by some speakers (e.g., ena megalo spiti, lit. 'a big house', is possible in parallel with ena spiti megalo). Other adjectives accepted in prenominal position by the speakers though not found prenominally in the texts are cinurio ('new, young') and paleo ('old'), which exhibit the same alternations in meaning between the pre- and postnominal position as seen in Romance (cf. (19)). The prenominal position of kalo ('good') and maño ('beautiful, nice'), largely found in the written sources, is accepted by the speakers as well. Notice also that in DPs with multiple adjectival modifiers no variety of Italiot Greek accepts more than one adjective in prenominal position. ${ }^{29}$ Finally, notice that, again like (Southern Italo-) Romance and unlike Standard Modern Greek, adjectives which occur prenom-

29 There are, actually, very few instances of DPs with multiple adjectives in the texts. 
inally seem not to be compatible with the interpretations typical of indirect modifiers, while those which occur postnominally are ambiguous between the non-restrictive/non-intersective interpretation and the restrictive/intersective one.

The evidence so far suggests the following conclusions:

- In Italiot Greek there is N/NP movement over prenominally merged adjectives. This property sets a major divide between Italiot Greek and Standard Modern Greek, where N/NP movement over adjectives is not possible.

- Indirect modifiers are only postnominal. Thus, it is reasonable to assume that they are merged in the same position where postnominal indirect modifiers are merged in Romance, and presumably in Greek.

An important issue is whether postnominal adjectives in definite DP s generate polydefinite constructions in Italiot Greek; in particular, one problem is how to account for the fact that, unlike Standard Modern Greek, in Italiot Greek postnominal adjectives are (assumed to be) generated from two distinct sources, only one of which would in principle be compatible with polydefiniteness (whose underlying structure is discussed in Section 4).

In Salento Greek, postnominal adjectives are never articulated: no trace of polydefinite constructions is found, as seen in (39). This is the second major difference between Italiot Greek and Standard Greek.

(39) meletisa ton libbro rodino

[Salento Greek] read.1PST the book red 'I read the red book'

Similar evidence is found in the currently spoken varieties of Calabria Greek: speakers tend to dislike polydefinite DP s, and when explicitly asked, they characterize them 'archaic' (cf. (4Oa) vs. (4ob)).

(40) a. $i$ daskoli cinuri iendonnusi tus daskalu paleu the teachers young imitate the teachers old

[Calabria Greek—spoken]

'Young professors imitate old teachers'

b. ??i daskoli $i$ cinuri iendonnusi tus daskalu tus paleu the teachers the young imitate the teachers the old 'Young professors imitate old teachers' (archaism) 
Yet, as noted in Guardiano \& Stavrou (2014), in the textual tradition of Calabria Greek ${ }^{30}$ postnominal adjectives are systematically articulated in definite argument DP $s$ as in $(41) .{ }^{31}$

(41) a. ta cerata ta makria

[Calabria Greek—written sources] the horns the long 'the long horns'

b. to lleddendu tom bovero the brother the poor 'the poor brother'

As already mentioned, there is at least one important difference between the polydefinite structures attested in the textual tradition of Calabria Greek and those of Standard Modern Greek: no traces of articulated adjectives occurring before the articulated noun, of the type to akrivo to amaksi, very common in Standard Modern Greek (see (14)), have been found. As pointed out earlier, this type of construction is almost absent from Ancient Greek texts (Manolessou 2000, Guardiano 2003).

Finally, it must be noted that instances of polydefinite structures are residually attested in traditional texts of Salento Greek, as well $((42)$ comes from a folk song), presumably depicting older stages of the language and, therefore, suggesting that the polydefinite pattern existed in the older times also in that variety.

(42) na vali ti guneddha ti kkali ci to mantili to that wear.2SG the skirt the beautiful and the apron the matassoto [Salento Greek—folk song] silk 'to wear the beautiful skirt and the silk apron'

Here, we assume that the presence of polydefinite structures in the older varieties of Italiot Greek is a relic of a system where polydefiniteness was fully

30 Which is likely to reflect the language spoken between the 19th and the early 20 oth century in the area (Guardiano \& Stavrou 2014).

31 Not unexpectedly, in the texts, the absence of an article with postnominal adjectives is possible in non-argument positions only: postnominal unarticulated adjectives in definite DP s are attested, for instance, in small clause structures, just like in Standard Modern Greek (Guardiano \& Stavrou 2014: 135-136, examples 48-49). 
productive. If this assumption is correct, one may wonder what may have triggered its loss. In Section 5 , we argue that the loss of polydefiniteness is one of the consequences of the adoption of N/NP-movement across prenominal adjectives.

Towards an analysis

\subsection{The basic questions and an overview}

The questions that arise with respect to the data presented in the previous section are: (a) how to account for the restrictions on the occurrence of prenominal adjectives in the two Greek varieties of Southern Italy; (b) how to account for the polydefinite patterns observed in the textual tradition of Calabria Greek and how to explain their loss in present day Italiot Greek.

The first question was answered by Guardiano \& Stavrou (2014). Their proposal, as already mentioned (Section 3.4), relies on the hypothesis that Italiot Greek adopted N/NP-movement over prenominally merged adjectives, and that this change happened under the pressure of contact with the neighboring Romance dialects. Their hypothesis is that the contact with Romance encouraged the interpretation of postnominal adjectives as ambiguous between the readings connected to direct modification and those connected to indirect modification; that, in turn, triggered the reanalysis of postnominal adjectives as originating prenominally and crossed over by $\mathrm{N} / \mathrm{NP}$, a process that had as a consequence the restrictions on prenominal adjectives illustrated above in $\left(3^{2-38)}\right.$.

As far as the second question is concerned, our hypothesis runs as follows: in Standard Modern Greek, postnominal adjectives are indirect modifiers (Stavrou 2012) which, we assume, originate inside a clausal structure. In particular, in the spirit of Campos \& Stavrou (2004), we assume a DP-internal predicative structure the head of which encodes the predication relation. This is purported to reflect the fact that, in polydefinite structures, the adjective and the noun are found in a predicative relationship-the noun representing the subject and the adjective representing the predicate-paraphrasable by a copulative clause (to vivlio to kalo, lit. 'the book the nice', can be paraphrased as 'the book is nice'). ${ }^{32}$ Importantly, the same holds of adjectives following the noun

32 It is worth mentioning here that the predicative relationship expressed by a clause and the relationship between the noun and the adjective in the polydefinite are not in a 
in an indefinite DP. Thus, ena vivlio akrivo (lit. 'one/a book expensive') means (ena) vivlio ine akrivo ('one/a book is expensive'). Of course, an IP, along the lines of Kayne (1994) as implemented for Greek by Alexiadou \& Wilder (1998), can also endorse the predicative relation.

The crucial part of this analysis is that the adjective is merged postnominally and it is an indirect modifier. Another very important aspect, mentioned also in Section 3.2 and repeated here for convenience, is that the morpheme that precedes the adjective in polydefinite DPs is the spell-out of definiteness and case, does not have meaning, and does not contribute to the interpretation of the combination noun-adjective (which is simply due to the character of the adjective as indirect modifier): the purpose of the article that precedes the adjective in polydefinite D P s is, therefore, solely grammatical or morphological.

\subsection{Polydefiniteness and nominal apposition}

To describe the grammatical requirements that motivate the need for the article in front of the adjective in polydefinite structures, we adopt the analysis proposed by Campos \& Stavrou $(2011,2012)$ for nominal apposition in Greek ${ }^{33}$ and in Spanish: (43) illustrates the Greek counterpart of the so-called 'N-of-N Construction' in English (e.g., that angel of a mother of his). ${ }^{34}$

$$
\begin{aligned}
& \text { o agelos } i \text { mitera tu } \\
& \text { the angel the mother his } \\
& {\left[{ }_{D P} D \quad\left[\operatorname{PredP}\left[{ }_{N P} \text { agelos }\right] \text { Pred }\left[{ }_{[+N]} \text { mitera tu }\right]\right]\right]}
\end{aligned}
$$

In appositive structures of the type shown in (43), two nouns in juxtaposition are involved, which always share the same case (assigned to the DP by an external case assigner). This case-sameness between the two nouns, a defining feature of nominal apposition in general, has replaced the older genitive (in

one-to-one correspondence; there are cases (admittedly exceptional), where the use of a polydefinite DP is infelicitous while the noun and the adjective are still in a predicative relation (Manolessou 2000).

33 For an alternative treatment of polydefinite DP s as close apposition, see Lekakou \& Szendroi (2012).

34 There is a vast literature on this construction and for a number of languages. We cannot list all or the majority of the relevant references here, and in any case, this construction is not our primary focus. For the earliest (contemporary) accounts see Milner (1978), Ruwet (1982), Napoli (1989); see also Matushansky (2002), Vişan (2003, 2006). 
the same constructions). ${ }^{35}$ It is further the equivalent of the prepositional genitive $^{36}$ that occurs in, e.g., Italian (quell'angelo disua madre, lit. 'that angel of his mother') or Spanish (el idiota del vecino, lit. 'the idiot of.the neighbor'; see Villalba 2007) and of the inflected genitive visible in Latin (monstrum mulieris, lit. 'monster woman.gen', Plaut. Poen. 273). Di, de, and English of are case assigners in the DP: they assign case to the predicate. No such case assigner is available in Standard Modern Greek. ${ }^{37}$ Its role has somehow been replaced by the identity of case between subject and predicate.

The other distinctive feature of appositive structures of the type exemplified in (43) is the obligatory "definiteness agreement" between the two nouns in apposition (i.e., both nouns must be preceded by a "definite article"). Campos \& Stavrou's analysis of nominal appositions crucially assumes that the feature that is spelled out as the definite article, which they label [+def], is found not only in D, but also in the head Pred of the PredP in (43), ${ }^{38}$ and is spelled out as the same morpheme, although this is not semantically the article. This happens because: (i) Pred is a nominal head and as such it has nominal features, including [+def] (because it belongs to the extended DP);39 (ii) the definite article is the default realization of the feature [+def]. By that we mean that whenever $\mathrm{D}$ is [+def] there is a definite article in the noun phrase (see also Kyriakaki 2011). What is important to note here is that [+def] does not encode semantic

35 Many grammars of ancient Greek include this particular use of genitive case under the label "genitive of apposition", of which there are examples in New Testament Greek, and which is described as follows: "the substantive in the genitive case refers to the same thing as the substantive to which it is related. The equation, however, is not exact. The genitive of apposition typically states a specific example that is a part of the larger category named by the head noun. It is frequently used when the head noun is ambiguous or metaphorical (hence the name 'epexegetical genitive' is quite appropriate) [...]. Every genitive of apposition, like most genitive uses, can be translated with of + the genitive noun. To test whether the genitive in question is a genitive of apposition, replace the word of with the paraphrase which is or that is, namely or, if a personal noun, who is" (Wallace 1996: 94100). The examples, however, are quite disputed. One of those most frequently mentioned

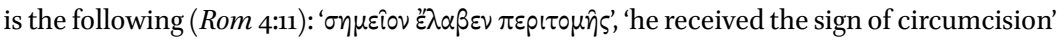
(i.e. 'the sign, which is circumcision').

36 This genitive is called in grammar books of various languages 'genitivus definitivus' and 'genitif appositionel'.

37 A similar construction occurs in Hebrew with šel, the equivalent of 'of', e.g. mótek šel oto 'sweetie of (a) car' (Botwinik \& Albert 2015: 8).

38 In the original analysis of Campos \& Stavrou (2011) there is a R(elational) $\mathrm{P}($ hrase $)$ between D and PredP that serves as a mediator of predication, along the lines of den Dikken (2006). For simplicity of exposition here we omit that projection since its theoretical importance does not affect or define our point of focus.

Grimshaw (1991), van Riemsdijk (1998). 
definiteness; indeed, it is spelled out as the definite article not only with definite nouns, but also with proper names and generic nouns. This means that the feature [+def] is a morphosyntactic feature rather than a semantic one, and that each and every realization of the definite article is the spell out of [+def]. Semantic definiteness, instead, has been assumed to be due to the presence of other categories in the nominal phrase. For instance, Kyriakaki (2011) argues that semantic definiteness is related to an Iota Phrase and/or a Familiarity Phrase. A similar proposal is also made by Lekakou \& Szendroi (2012), who treat the definite article as semantically expletive and locate semantic definiteness in a different functional head inside the nominal phrase, namely, DefP.

One important similarity between nominal appositives and polydefinites is that they both encode definiteness and morphological case agreement. Thus, in order to capture the nature of polydefinites, transferring to them the analysis for appositives proposed by Campos \& Stavrou seems to be a natural step forward. ${ }^{40}$ We therefore propose that adjectives in polydefinites originate as predicates in the complement of Pred. The noun (or NP), on the other hand, is in the specifier of PredP. A simplified version of the proposed structure is given in (44).

$\begin{array}{rlll}(44)\left[{ }_{D P}\right. & \mathrm{D} \\ {[+\mathrm{def}]} & {\left[\operatorname{PredP}\left[{ }_{\mathrm{NP}} \text { amaksi }\right]\right.} & \text { Pred } \\ \text { to } & & {[+\mathrm{def}]} & \left.\left.\left[{ }_{[+\mathrm{N}]} \text { akrivo }\right]\right]\right] \\ \text { the } & \text { amaksi } & \text { to } & \text { akrivo } \\ & \text { car } & \text { the } & \text { expensive }\end{array}$

We assume that the adjectival article is the spell-out of Pred, just like in appositives according to Campos \& Stavrou. The crucial part of this analysis ${ }^{41}$ is that the feature [+def] is again carried by both $\mathrm{D}$ and Pred. Pred, by virtue of being

40 It must be said at this point that Alexiadou (2014: Chapter 2) argues against the unification of nominal apposition (close apposition, pseudo-partitives) and polydefiniteness, listing a number of differences between the two. Although a detailed discussion of the issue goes well beyond the purpose of the present paper, we can only say here that most of those differences (admittedly non-trivial) stem from the different categorial status of the elements in apposition and the concomitant special semantics found in nominal apposition: in appositive structures both elements are nouns (of a special kind) - the structure is also called for this reason "binominal $\mathrm{NP}$ "-while in polydefinites one of the elements is an ordinary adjective and the other a noun (Campos \& Stavrou 2011, 2012).

41 Campos \& Stavrou (2004) have a structure slightly more complex than that in (44), because $\mathrm{D}$ and $\mathrm{N}$ form a single unit in $\mathrm{D}$, and the specifier of PredP would host the demonstrative. Here we do not want to get into such details, which do not affect the main point of analysis. For an analysis of the position of demonstratives in the nominal phrase in Greek and their relation to PredP see also Guardiano \& Michelioudakis (2019). 
a nominal head, carries all the relevant nominal features (gender and number, case, and definite/indefinite). The unvalued [+def] feature on Pred is valued (as probe) by the [+def] feature on D, and it is spelled out as the morpheme identified as the definite article (default realization) in both cases. It is in this way that "double" definiteness (or definiteness spread) can be accounted for: Pred agrees with D in definiteness (along with case, gender, and number), and they are realized in exactly the same way.

In Standard Modern Greek, within a single noun phrase, nouns and modifying adjectives show concord ${ }^{42}$ in phi-features and case. In the light of this robust rule, we make the following hypothesis: if the adjective is merged prenominally, concord is effected straightforwardly, given the Spec-Head configuration adjective and noun are found in (Cinque 2010; Giusti 2008, 2009, 2011; see also Koopman 2006). If the adjective is merged postnominally (as we assume is the case with adjectives in the polydefinite construction) this kind of concord is not available. Therefore, some mediator is required. The Pred head takes up precisely that function: it mediates concord in "definiteness", phi-features, and case between noun (subject) and adjective (predicate). More specifically, the head of PredP shows concord with the NP at its specifier and the NP shows concord with the adjective via predication. In the final spell-out of (44), to amaksi to akrivo, noun and adjective concord in definiteness, case, and phi-features. ${ }^{43}$ In Standard Modern Greek, this concord has overt morphological exponence. The morphological realization of case, indeed, is a prominent feature of Standard Modern Greek: as a rule, within a DP, the noun and its adjectival modifier(s) bear overt case morphology. This overt concord is sometimes blurred by some syncretism in the declensional system: as we see in Section 5 , this is a crucial point where Standard Modern Greek differs from Italiot Greek, where syncretism is much more advanced.

Concerning the morphological realization of case, an important part of the proposed analysis of polydefiniteness as a structure essentially similar to apposition is the assumption that, in Standard Modern Greek, the lexicalization of the [+def] feature has the further effect of realizing morphological case on

42 Here we use the term "concord" following Giusti (2008, 2009, 2011) who argues extensively that concord is a consequence of the Spec-Head relation and is different from Agreement, if what is intended is the "agreement" between verb and subject. For Giusti $(2008,2009$, 2011), agreement is a consequence of selection, while concord is a consequence of modification.

43 The order to akrivo to amaksi ('the expensive the car') is also common and, as observed above, it is due to the movement of the constituent [art+AP] to some projection above DP. In fact, even the sequence [art+noun] can be moved higher to a topic position (vacuous) movement (Ntelitheos 2003, 2004; Alexiadou 2014: 38). 
Pred. In other words, [+def] and case are inextricable; this means that wherever there is a morpheme that spells out [+def] there will also be (morphological) case. We conjecture at this point that the very reason why the functional head Pred takes up the form of the definite article is the fact that the degree of syncretism is less on the article than on any other nominal category (noun, adjective, quantifier), in the sense that there are more case distinctions visible on the definite article than on other nominal heads. To give a concrete example, feminine nouns have syncretized the affixes for the nominative and the accusative case in the two numbers: agapi ('love') can be either nominative or accusative; the two cases can be formally distinguished only if the definite article is present, since it has two different forms for the two cases in question: iagapi ('the.nom love') is nominative, tin agapi ('the.acc love') can be only accusative. That is exactly the root of the phenomenon of definiteness and case agreement in appositive structures, and more generally in Greek.

To sum up, from the assumption that postnominal adjectives in Standard Greek (in both definite and indefinite structures) are merged as indirect modifiers, it can be deduced that the presence of the definite article on postnominal adjectives in the Greek polydefinite construction has a purely formal role: it is just the spell-out of a functional head (Pred) which makes the adjective concord with the noun in definiteness, case, and phi-features. ${ }^{44}$

The question that naturally arises at this point is whether Romance is subject to the same analysis. Leaving aside postnominal adjectives that are crossed over by the noun (or the NP), postnominal adjectives that are indirect modifiers can in principle be analyzed as predicates. Our hypothesis is that genuinely postnominal adjectives in Romance can also be part of some type of predicative clause/reduced relative structure. ${ }^{45}$ However, the predicative head is

44 As far as indefinite DPs with the sequence NA are concerned (see (10)), the structure is the same as in (44). However, the [-def] feature that is present on both D and Pred does not have a lexicalization, because default realization of [-def] is zero in Greek. Still, concord between adjective and noun holds as in the definite cases. It is achieved through the relation of predication, again mediated by Pred, though with [-def] Pred and D remaining silent. In contrast, concord in phi-features and case is visible as in definite DP s. A crucial fact is that the morpheme for the indefinite article (and the numeral) enas ('one/a') is not in D but lower, in QP or NumP. This is an assumption shared by many researchers (Alexiadou \& Wilder 1998, Stavrou 2012, Alexiadou 2014, among others). Thus, it is not unreasonable to posit polyINdefiniteness too, since in indefinite DPs concord in the feature [-def] between D and Pred does exist.

45 Notice that the structure in (44) does not predict the possibility of multiple postnominal adjectives in one and the same DP, nor the presence of a prepositional phrase between the noun and the adjective. The judgements of the speakers of Standard Greek are actually quite variable on these aspects (Alexiadou \& Wilder 1998). Notice that in the textual 
not lexicalized systematically. It is lexicalized in Romanian and in Aromanian (Campos 2012 and references therein) as the pseudo-article cel in the former and as the suffixed article $-l(u)$ in the latter (see also Campos \& Stavrou 2004). In contrast, in Western Romance, it is not lexicalized as a rule with adjectival modifiers (most likely because the feature [+def] is not by default lexicalized as in Greek $)^{46}$ but is actually visible in some selected constructions: for instance, in French (Kayne 2004), postnominal superlative adjectives must obligatorily have a second determiner when occurring in postnominal position (la fille la plus grande, lit. 'the girl the most big'). So, whether the predicative head is spelled out or not seems to be subject to gradable parametric choices, which probably also depend on the type of predicative head itself (and its position in the DP), on whether [+def] is lexicalized by default, and also (possibly) whether a language has case morphemes and morphological case agreement, and whether morphological case is realized on the definite article.

An interesting discussion of these phenomena in a broader crosslinguistic perspective, with particular reference to Albanian varieties, Aromanian, and Romanian, is proposed in Manzini \& Savoia (2018, Part II), with reference to the so-called 'Linkers', a label that covers, in their description, several types of constructions involving different types of adnominal modifiers, including "Linkers, Greek article, Iranian ezafe, etc" (Manzini \& Savoia 2018: 127). They propose that "in Aromanian and Albanian Linkers are Ds" and connect their distribution to "the minimalist rule of Agree". Their analysis goes actually beyond the purposes of the present investigation, and, although there are commonalities between our conception of D and Pred and their Linkers, the two approaches differ in many respects, most crucially in the dissociation of Linkers from copulas. Yet, there are several interesting aspects which might combine with our discussion of polydefiniteness in a broader crosslinguistic picture.

tradition of Calabria Greek where polydefinite structures are found, there are no instances of multiple postnominal adjectives. We are also aware of the fact that there are differences between Greek and Romance with respect to precisely the same points: the positioning of postnominal adjectives, the presence of a prepositional phrase between the noun and the adjective, and to the possibility of the appearance of multiple postnominal adjectives in one and the same DP. The possibilities available to Romance speakers seem to be much less constrained in this respect. However, such differences are not directly related to our main concern and so we leave the issue to future further exploration.

46 Alexopoulou \& Folli (2019) have suggested that a difference between Western Romance and Greek is that, while the former allows a null D, the latter does not. 
What is crucial for the purposes of the discussion in the next section is that, as far as Greek is concerned, there is a strong correlation between the spell-out of the Pred head, definiteness and (morphological) case. ${ }^{47}$

\section{5}

\section{The loss of polydefiniteness in Italiot Greek}

Having said all the above, we are now in a position to discuss the data of Italiot Greek.

It must be first observed that the Greek dialects of Southern Italy display the same properties as Standard Modern Greek as far as the behavior of definite articles is concerned: the definite article is required with definite noun phrases, with kind-referring nouns, and with proper names (Guardiano \& Stavrou 2014, Guardiano et al. 2016). Thus, it seems that in Italiot Greek the feature that we labelled [+def] in Section 4.2 (which, as in Standard Modern Greek, must always spell out $\mathrm{D}$ ) encodes syntactic properties which do not necessarily entail (just) the semantic representation of definiteness, precisely like in Standard Greek. No internal variation is found in this respect between Salento and Calabria Greek.

As far as the morphological representation of case is concerned, it has variously been remarked that, in both Salento (Melissaropoulou 2012) and Calabria (Katsoyannou 1996, 2001) Greek, case distinctions have the tendency to progressively disappear: nominal and adjectival paradigms display various irregularities, and this has been interpreted as a signal that the case system is undergoing a progressive evolution towards morphological simplification via syncretism. For instance, Katsoyannou $(1996,2001)$ notes that, in Calabria Greek, feminine nouns have the fewest types: one for the singular and two for the plural; moreover, many masculine nouns have one single form for the nominative and accusative singular. Thus, it seems that the morphological structure of the case system in Italiot Greek is less robust than that of Standard Modern Greek. This has important consequences in the overt case agreement between nouns and adjectives within DP s: most DPs do not display overt instances of case concord. ${ }^{48}$

It must be further recalled that both Salento and Calabria Greek display two important differences with respect to Standard Modern Greek as far as the posi-

\footnotetext{
47 For the relation between polydefiniteness and Kase, see also Lekakou \& Szendroi (2012).

48 Notice, nonetheless, that (definite) articles display less syncretism in case morphology than nouns and adjectives, just like in Standard Modern Greek.
} 
tion of adjectival modifiers with respect to the head noun is concerned. The first is that Italiot Greek has strict constraints on the occurrence of prenominal adjectives. The second is that the currently spoken varieties of Italiot Greek have lost polydefiniteness. The latter seems to be a recent phenomenon: indeed, as pointed out above, older varieties of both Salento and Calabria Greek actually feature instances of polydefinite DPs. Yet, the loss of polydefiniteness seems to have proceeded at a different pace in the two groups: in Calabria Greek, polydefinite DP s are attested up to recent times, while in Salento polydefinite structures only appear in fossilized expressions. A further interesting fact, seen in particular in the Calabria Greek texts where polydefiniteness is visible, is that the restrictions on prenominal adjectives were introduced before the loss of polydefiniteness: as shown in Guardiano \& Stavrou (2014), the textual tradition of Calabria Greek features very few prenominal adjectives, and postnominal adjectives take systematically their own article in definite DP s.

Notice, finally, that postnominal adjectives occurring in polydefinite DP s in Calabria Greek cannot be iterated (there are no instances of multiple postnominal adjectives occurring in one and the same polydefinite DP in the corpus examined): this makes them actually compatible with the structure in (44), under the assumption that there is only one predicative structure per DP/Clause. Instead, multiple postnominal adjectives are allowed in the currently spoken varieties, in which they do not occur in polydefinite DP s. Therefore, it seems reasonable to assume that postnominal adjectives in present day Italiot Greek have some additional source different from (44). First of all, the possibility of linearizing adjectives in prenominal position, although restricted to very few cases, suggests that Italiot Greek has kept the originally prenominal source, where adjectives are merged as direct modifiers and realize phi-feature concord via Spec-Head. In those cases, there is no clausal structure, hence no Pred head. In the absence of Pred, the feature [+def] is only carried by D; as a consequence, it is spelled out only once in the nominal structure, giving rise to a "monadic" DP. As observed in Section 3.4, the adjectives which belong to classes found in the lower positions of the semantic hierarchy in (3), assumed to be merged closer to the noun (prenominally), are systematically linearized postnominally in Italiot Greek. These patterns, which resemble those observed in Romance and which are actually identical to those found in Southern Italo-Romance, have been analyzed by Guardiano \& Stavrou (2014) as a consequence of N/N P-movement. As suggested by Guardiano \& Stavrou (2014; see also Guardiano et al. 2016, Guardiano et al. 2018), the emergence of N/NPmovement is an innovation when compared to the rest of the Greek-speaking world: no movement of the noun across prenominally merged adjectives is attested in any other ancient or contemporary variety of Greek (Guardiano et 
al. 2016). Guardiano \& Stavrou (2014) hypothesize that contact with Southern Italo-Romance might have played a role in the introduction and spread of such an innovation. This is one of the major changes which affected the syntax of nominal phrases in Italiot Greek, setting it apart from the rest of the Greekspeaking world.

Our hypothesis is that the loss of polydefiniteness is linked to such a change. We assume that, originally, in Italiot Greek, as in Standard Modern Greek (and, as a matter of fact, as in Ancient Greek), direct modification adjectives were merged in prenominal position and were not crossed over by the noun, and that postnominal adjectives were only interpreted as indirect modifiers, generated postnominally in a structure of the type shown in (44), which resulted in polydefinite constructions with definite DPS.

Notice that, in Greek, postnominal adjectives in indefinite DP s superficially do not exhibit any special feature that distinguishes them from prenominal ones, precisely as in Romance (cf. (10)). According to Guardiano \& Stavrou (2014) and Guardiano et al. (2016), it was precisely the availability of such Noun-Adjective sequences, identical to those of Romance (which, incidentally, emerged from two potential sources: N/NP-movement over originally prenominal adjectives and the predicative structure), which triggered, in Italiot Greek, the reanalysis of postnominal adjectives as originally merged prenominally and crossed over by N/NP.

It is also part of our hypothesis that PredP lost the need to make its head (Pred) visible. We assume that this change was triggered by the aforementioned restructuring of the nominal declensional system. One might conjecture that, as syncretism advanced and case distinctions were blurred or lost on both adjectives and nouns (with the consequence that the nominal declensional system is getting closer to that of Southern Italo-Romance), the necessity of Pred as a mediator of (case) concord was made dispensable with: morphological concord in case between the noun and the adjective is (no longer) visible systematically in those dialects. Thus, the presence of the adjectival article in the polydefinite sequences visible in the textual tradition of Calabria Greek cannot be explained in terms of the realization of morphological case concord between the noun and the adjective (which, as seen in Section 4.2, is a crucial aspect in the explanation of polydefiniteness in Standard Modern Greek). In other words, it is very likely that the DP s which superficially look like polydefinite structures in the textual tradition of Calabria Greek are actually residual instances of (44), because in fact they do not realize the full array of properties seen for these type of structures in Standard Modern Greek. Empirically, they actually display some aspects which are consistent with the patterns described for Standard Modern Greek in Section 4.2, notably the presence of the adjec- 
tival article and the impossibility of multiple postnominal adjectives. Yet, contextually, some of the properties exhibited by polydefinite DPs in Standard Modern Greek are absent: for instance, as seen above, polydefinite DP s with prenominal articulated adjectives (of the type to akrivo to amaksi 'the expensive the car'), which are quite productive in Standard Modern Greek, are not attested in the texts which we explored.

Another point of internal inconsistency is the following. If it is true that, at the stage illustrated by the textual tradition of Calabria Greek, the language had two sources for postnominal adjectives, namely the prenominal position crossed over by N/NP and a postnominal position of the type shown in (44), one would expect only the latter to give rise to a polydefinite DP. Instead, what we see is that all postnominal adjectives have their own article (in definite DP s). So, we might conjecture that, at this stage, the article that appears on postnominal adjectives in definite DP s is just a definiteness agreement morpheme attached to every postnominal adjective, rather than the actual spell-out of Pred. A similar type of definiteness agreement morpheme is in fact visible in other varieties of Greek (for instance Asia Minor Greek; see Guardiano et al. 2016): this morpheme appears (obligatorily) with all types of noun modifiers (not just with adjectives), which in these varieties are overwhelmingly prenominal (structures of the type shown in (44) are absent from Asia Minor Greek; Guardiano et al. 2016). What we see in Italiot Greek is the next step forward, namely the complete elimination of definiteness agreement morphemes: this might have been not unreasonably triggered by contact with the neighboring Romance dialects, where no overt definiteness or case agreement between the noun and a postnominal adjective is seen, and where no "Linker" appears between the two. ${ }^{49}$

Let us sum up. Superficially, the patterns of adjectival modification currently observed in Italiot Greek are identical to those visible in the neighboring Southern Italo-Romance dialects. Yet, while the latter (with few interesting exceptions, discussed in Guardiano \& Stavrou 2014) are quite compatible with the rest of Romance, Italiot Greek has introduced several innovations with respect to the patterns observed in Greek. Thus, it would be reasonable to conjecture that such innovations were introduced as a consequence of contact with Romance, namely that Italiot Greek has borrowed its current patterns from Romance. Yet, a closer observation of the internal structure of the morphosyn-

49 We do not know whether the steps delineated here actually correspond to identifiable specific diachronic stages. In order to check it, a detailed exploration of historical documentation and texts (if available) is needed, and is left for further investigation. 
tactic system of adjectival modifiers across the Greek-speaking world suggests that these changes cannot be simply due to a mechanical borrowing of linear patterns. First of all, it must be noticed that essentially all the patterns available in the currently spoken varieties of Italiot Greek are also available in (Ancient and Modern) Greek: postnominal adjectives not preceded by their own article are possible in indefinite DP s, and originally prenominal adjectives are widespread in the language. What happened in Italiot Greek is that those patterns were reanalyzed and extended to contexts in which they are not possible in the rest of Greek (e.g., postnominal adjectives with no article became acceptable in definite DPs).

Actually, some of the changes which might have potentially triggered the processes of reanalysis that generated the new system seem to be contingent upon changes in the morphosyntactic structure of the declensional system.

However, it is also quite unlikely that contact did not have any role in the changes under discussion. It is not unlikely, instead, that extensive contact with Romance made available to the speakers of Greek empirical evidence which favored the process of reanalysis. This is consistent with the predictions of Guardiano et al.'s (2016) Resistance Principle, originally formulated as a generalization over the potential constraints acting on parameter change under contact, and inspired by the inertial view of syntactic change proposed by Keenan (1994) and then implemented by Longobardi (2001 and subsequent works). The Resistance Principle predicts the following:

... the resetting of a parameter under the influence of interference data is possible only if the new triggers are similar enough to triggers already unmistakably present in the interfered language, though of course not sufficient on their own to trigger the new value. The informal idea is that interference data in parametric syntax must appear, at least partially, as familiar in the interfered language, in order to be used as triggers, hence contact may exacerbate/reinforce existing tendencies.

GUARDIANO ET AL. 2016: 148

One of the examples of how the Resistance Principle operates proposed by Guardiano et al. (2016) is the realization of the definite article as a bound morpheme in the languages which are spoken around the Black Sea (and have an article): this seems to be an actual areal feature that crosses genealogical groupings. Guardiano et al. (2016: 149) propose that it started from structures which were actually independently available in all these languages; in particular, they suppose 
... that all affected varieties must already exhibit articles occurring as free morphemes but often adjacent to the noun, in positions compatible with immediate reanalysis as bound morphemes: this must obviously have been the case in previous stages of Pontic Greek.

Another example proposed is precisely the development of noun movement over prenominally merged adjectives that happened in Italiot Greek, which we discussed above. We further hypothesize that the latter change was in turn one of the factors that triggered the process of loss of polydefiniteness, because it generated linear sequences NA which could not be analyzed as the output of (44) and instead were identical, in terms of both linear order and interpretation, to those visible in Southern Italo-Romance. Recall that, in those dialects, the head of the (predicative) clause in which indirect modification adjectives are generated (namely Pred or its equivalent) is not spelled out. The other change, namely the loss of robust case morphology, was in turn triggered by the morphological system rather than by the syntax (and this is consistent with inertial principles), and produced patterns not too dissimilar to those of Southern Italo-Romance, where no visible morphological agreement in case between nouns and adjectival modifiers is seen.

If this line of reasoning is on the right track, the next step is the extension of our analysis to other languages that exhibit (some form of) polydefiniteness. Aromanian is a case at point. Although it appears that this language presents us with counterevidence-insofar as the adjective bears the article -ul-it, in fact, supports our analysis. Aromanian is in contact with (Mainland) Greek, in which all varieties manifest polydefiniteness. So, it does not come as a surprise that Aromanian also manifests polydefiniteness (Campos \& Stavrou 2004). A further observation concerning Aromanian is that the (adjectival) article is a bound morpheme (suffix): apparently, that is one more factor that encourages the preservation of the polydefinite pattern. On the other hand, Arbëresh (Albanian in Southern Italy and thus in contact with Italian; see Manzini \& Savoia 2018) is apparently a problem for us, because the preadjectival article is preserved although the case system is simpler than in Standard Albanian. Further research, especially concerning the structure of the adjectival modification system and its relation with N/NP-movement, as well as the patterns of morphological realization of case and agreement, is needed in order for solid typological generalizations to be made, and thus for potential counterevidence to be minimized. But that kind of research we leave to the not too distant future. 
In this article, we presented some patterns of adjectival modification visible in Romance and in Greek of Southern Italy, and we proposed a syntactic account of those patterns.

The constraints observed on superficially prenominal adjectives in Italiot Greek are likely to strictly depend on N/NP-movement, like in the neighboring Southern Italo-Romance dialects. Concerning this aspect, Italiot Greek represents an interesting exception with respect to Standard Modern Greek, where no N/NP-movement over prenominal adjectives is attested.

Adjectives which act as indirect modifiers and which appear postnominally are assumed to be merged in a predicative structure that is originally postnominal. In (non-Italiot) Greek, adjectives generated in such a structure require a visible article, for reasons of definiteness, phi, and case concord, while in Italiot Greek they are regularly not articulated. However, Italiot Greek witnesses instances of polydefiniteness at older stages of its history. We propose that the loss of polydefiniteness in Italiot Greek follows from two interrelated factors: (i) the reanalysis of (some) postnominal adjectives as merged prenominally, and (ii) the internal restructuring of the case system that eliminated the need of an overt case agreement marker. Such a process seems to have happened gradually: the written texts of Calabria Greek, where postnominal adjectives are systematically articulated in definite DPs, seem to reflect an intermediate stage, where the role of the adjectival article as an overt mediator of case concord between nouns and adjectives originating postnominally is already lost.

\section{Acknowledgments}

We want to thank our informants: Rocco and Marcello Aprile, Francesca Ciantia, Silvio Cruschina, Franco Fanciullo, Carmelo Giuseppe Nucera, Salvino Nucera, Giuseppina Silvestri, Agostino Siviglia', Salvatore Siviglia, Maria Olimpia Squillaci, Bruno Traclò, Filippo Violit. We also thank Hilda Koopman, Pino Longobardi, Tim Stowell, and the audience of TEAM2O17 and DIGS2017 for discussion and feedback. All mistakes are ours. This work was partially supported by the ERC advanced grant n. 295733 . 


\section{References}

Abels, Klaus \& Ad Neeleman. 20og. Universal 20 without the LCA. In: Merging Features, ed. by José M. Brucart, Anna Gavarro, \& Jaume Sola, 6o-79. Oxford: Oxford University Press.

Abney, Steven. 1987. The English noun phrase in its sentential aspect. MIT PhD Dissertation.

Alexiadou, Artemis. 2001. Adjective syntax and noun raising: Word order asymmetries in the DP as a result of adjective distribution. Studia Linguistica 55: 217-248.

Alexiadou, Artemis. 2014. Multiple determiners and the structure of DPs. Amsterdam: John Benjamins.

Alexiadou, Artemis, Liliane Haegeman \& Melita Stavrou. 2007. The noun phrase in the generative perspective. Berlin: De Gruyter.

Alexiadou, Artemis \& Chris Wilder. 1998. Possessors, predicates and movement in the DP. Amsterdam: John Benjamins.

Alexopoulou, Theodora \& Raffaella Folli. 2019. Topic strategies and the internal structure of nominal arguments in Italian and Greek. Linguistic Inquiry. [DOI: https://doi .org/10.17863/CAM.17233]

Androutsopoulou, Antonia. 1995. The licensing of adjectival modification. In: Proceedings of the fourteenth West Coast Conference of Formal Linguistics, ed. by Jose Camacho, Lina Choueiri \& Maki Watanabe, 17-31. Stanford, CA: CSLI Publications.

Aprile, Giannino. 1972. Calimera e i suoi traúdia. Galatina: Editrice Salentina.

Aprile, Rocco. 1998. Canti d'amore della Grecia Salentina. Thessaloniki:Malliaris-Paedia. Aprile, Rocco, Gustavo Buratti, Gerard Rohlfs \& Lina Colella. 1978. Grecia Salentina, problemi e documenti, Vol I. Cavallino: Lorenzo Capone Editore.

Aprile, Rocco, Giuseppe Lisi, Maria Montinaro \& Franco Corlianò. 198o. Grecia Salentina, problemi e documenti, Vol II. Cavallino: Lorenzo Capone Editore.

Bernasconi, Francesco. 2011. Il sintagma nominale in greco classico. Un sondaggio sugli oratori attici. Università di Trieste BA Thesis.

Bernstein, Judy. 1991. DP s in French and Walloon: Evidence for parametric variation in nominal head movement. Probus 3(2): 101-126.

Bernstein, Judy. 1993. Topics in the syntax of nominal structure across Romance. CUNY Ph.D. Dissertation.

Bolinger, Dwight L. 1967. Adjectives in English: attribution and predication. Lingua 18: 1-34.

Bouchard, Denis. 2002. Sériation des adjectives dans le SN et formation de concepts. Recherches Linguistiques de Vincennes 34: 125-142.

Botwinik, Irena \& Aviad Albert. 2015. Prosodic prominence in Hebrew binominal constructions: The occurrence of šel. In: $p S$-prominenceS: Prominences in Linguistics. Proceedings of the International Conference, ed. by Amedeo De Dominicis, 8-26. Viterbo: DIs Ucom Press. 
Campolo, Irene. 2002. Storia linguistica della romaicità bovese. Consuntivo e prospettive. Bova: Apodiafazzi.

Campos, Hector. 2012. Definite adjectives in Aromanian and Romanian: Pf-lowering, Agreement or Concord? Paper presented at the Balkan Romance Contacts Workshop. Università Ca' Foscari, Venice, March 13, 2012.

Campos, Hector \& Melita Stavrou. 2004. Polydefinites in Greek and Aromanian. In: Balkan syntax and semantics, ed. by Olga Tomic, 137-173. Amsterdam: John Benjamins.

Campos, Hector \& Melita Stavrou. 2011. Definiteness effects in Spanish and Greek (appositive) nominals. Paper presented at Colloquium on Generative Grammar (CGG), Sevilla, April 7-9, 2011.

Campos, Hector \& Melita Stavrou. 2012. Emotional appositives in Spanish, Greek and Balkan Romance. Presentation at the Workshop on Balkan-Romance Linguistics. Università Ca' Foscari, Venice, March 13, 2012.

Capialbi, Ettore \& Luigi Bruzzano. 1885. Racconti greci di Roccaforte. Monteleone: Francesco Raho.

Caracausi, Girolamo \& Giuseppe Rossi Taibi. 1959. Testi neogreci di Calabria. Palermo: Istituto Siciliano di Studi Bizantini e Neoellenici.

Cinque, Guglielmo. 1994. On the evidence for partial N-movement in the Romance DP. In: Studies in honor of Richard S. Kayne: Paths towards Universal Grammar, ed. by Guglielmo Cinque, Jan Koster, Jean-Yves Pollock, Luigi Rizzi \& Raffaella Zanuttini, 85-110. Washington DC: Georgetown University Press.

Cinque, Guglielmo. 1999. Adverbs and functional heads: A cross-linguistic perspective. New York: Oxford University Press.

Cinque, Guglielmo. 2005a. The Dual Sources of Adjectives and XP vs. N-raising in the Romance DP. Unpublished Manuscript, Università Ca' Foscari, Venice.

Cinque, Guglielmo. 2005b. Deriving Greenberg's Universal 20 and its exceptions. Linguistic Inquiry 36: 315-332.

Cinque, Guglielmo. 2010. The Syntax of adjectives. A comparative study. Cambridge, MA: MIT Press.

Comparetti, Domenico. 1866. Saggi sui dialetti Greci dell'Italia meridionale. Pisa: Fratelli Nistri.

Condemi, Filippo. 1995. La grammatica grecanica. Cumelca: Editrice ellenofoni di Calabria.

Cornilescu, Alexandra. 2006. Modes of semantic combination: NP/DP adjectives. In: Romance Languages and Linguistic Theory 2004, ed. by Jenny Doetjes \& Paz Gonzalez, 43-71. Amsterdam:John Benjamins.

Cornilescu, Alexandra \& Alexandru Nicolae. 2011. Nominal peripheries and phrase structure in the Romanian DP. Revue Roumaine de Linguistique 56: 35-68.

Crisma, Paola. 1991. Functional categories inside the noun phrase. A study on the distribution of nominal modifiers. Università Ca' Foscari, Venice MA Thesis 
Crisma, Paola. 1996. On the configurational nature of adjectival modification. In: Grammatical Theory and the Romance Languages, ed. by Karen Zagona, 71-93. Amsterdam: John Benjamins.

Crupi, Giovanni Andrea. 1980. La 'glossa' di Bova; cento favole esopiche in greco calabro; schema grammaticale; lessico. Roccella Ionica: Associazione Culturale Ionica.

Cuomo, Luisa. 1977. Antichissime glosse salentine nel codice ebraico di Parma, De Rossi 138. Medioevo romanzo 4: 185-271.

Delsing, Lars Olaf. 1993. The internal structure of noun phrases in the Scandinavian languages. Lund University PhD Dissertation.

Demonte, Violeta. 1999. El adjetivo: clases y usos. La posicion de l'adjetivo en el sintagma nominal. In: Gramatica descriptiva de la lengua espanola, ed. by Ignacio Bosque \& Violeta Demonte, 129-215. Madrid: Espasa-Calpe.

den Dikken, Marcel. 2006. Relators and linkers: The syntax of predication, Predicate Inversion, and copulas. Cambridge, MA: MIT Press.

Dorian, Nancy. 1977. The Problem of the Semi-Speaker in Language Death. International Journal of the Sociology of Language 12: 23-32.

Falcone, Giuseppe. 1973. Il dialetto romaico della bovesia. Milano: Memorie dell'Istituto Lombardo di Scienze e Lettere.

Fanciullo, Franco. 2001. On the origins of Modern Greek in Southern Italy. In: Proceedings of the first international conference of Modern Greek dialects and linguistic theory, ed. by Angela Ralli, Brian Joseph \& Mark Janse, 67-77. Patras: University of Patras.

Franco, Ludovico, M. Rita Manzini \& Leonardo Savoia. 2015. Linkers and agreement. The Linguistic Review 32(2): 277-332.

Giusti, Giuliana. 1993. La sintassi dei determinanti. Padova: Unipress.

Giusti, Giuliana. 2002. The functional structure of noun phrases: A bare phrase structure approach. In: Functional structure in DP and IP, ed. by Guglielmo Cinque, 54-99. Oxford: Oxford University Press.

Giusti, Giuliana. 2005. At the periphery of the Romanian noun phrase. In: On space and time in language, ed. by Marie Coene \& Liliane Tasmowski, 23-49. Cluj Napoca: Clusium.

Giusti, Giuliana. 2006. Parallels in clausal and nominal periphery. In: Phases of interpretation, ed. by Mara Frascarelli, 163-186. New York: Mouton de Gruyter.

Giusti, Giuliana. 2008. Agreement and concord in nominal expressions. In: The BantuRomance connection, ed. by Cècile De Cat \& Katherine Demuth, 201-237. Amsterdam: John Benjamins.

Giusti, Giuliana. 2009. On feature sharing and feature transfer. University of Venice Working Papers in Linguistics 19: 157-174.

Giusti, Giuliana. 2011. On concord and projection. Bucharest Working Papers in Linguistics 13(1): 103-124. Unpublished Manuscript, Università Ca' Foscari, Venice. 
Grimshaw, Jane. 1991. Extended projections. Unpublished Manuscript, Brandeis University, Waltham, MA.

Grohmann, Kleanthes \& Phoevos Panagiotidis. 2004. Demonstrative doubling. Unpublished Manuscript, University of Cyprus and Cyprus College, Nicosia.

Grosu, Alexander. 1988. On the distribution of genitive phrases in Romanian. Linguistics 26: 931-949.

Gruppo di Lecce. 1980. Il caso Grecìa. In: I dialetti e le lingue delle minoranze di fronte allitaliano, ed. by Federico Albano Leoni, 343-403. Roma: Bulzoni.

Guardiano, Cristina. 2003. Struttura e storia del sintagma nominale nel Greco Antico. Ipotesi parametriche. Università di Pisa PhD Dissertation.

Guardiano, Cristina. 2014. Fenomeni di contatto sintattico in Italia meridionale? Alcune note comparative. Quaderni di lavoro ASIt 18: 73-102.

Guardiano, Cristina. 2016. Definite articles in Ancient Greek. In: Proceedings of the 26th annual UCLA Indo-European Conference, ed. by Stephanie W. Jamison, H. Craig Melchert, \& Brent Vine, 27-46. Bremen: Hempen.

Guardiano, Cristina \& Melita Stavrou. 2014. Greek and Romance in Southern Italy: History and contact in nominal structures. L'Italia dialettale 75: 121-147.

Guardiano, Cristina, Dimitris Michelioudakis, Andrea Ceolin, Monica-Alexandrina Irimia, Giuseppe Longobardi, Nina Radkevich, Giuseppina Silvestri \& Ioanna Sitaridou. 2016. South by Southeast. A syntactic approach to Greek and Romance microvariation. L'Italia dialettale 77: 95-166.

Guardiano, Cristina, Dimitris Michelioudakis, Guido Cordoni, Monica-Alexandrina Irimia, Nina Radkevich \& Ioanna Sitaridou. 2018. Parametric comparison and dialectal variation. Insights from Southern Italy. In: Romance languages and linguistic Theory 14: Selected papers from the 46th symposium on Romance languages (LSRL), Stony Brook, NY, ed. by Lori Repetti \& Francisco Ordonez, 103-133. Amsterdam: John Benjamins.

Guardiano, Cristina \& Dimitris Michelioudakis. 2019. Syntactic variation across Greek dialects: The case of demonstratives. In: Italian dialectology at the interface, ed. by Silvio Cruschina, Adam Ledgeway \& Eva-Maria Remberger, 319-355. Amsterdam: John Benjamins.

Horrocks, Jeoffrey \& Melita Stavrou. 1987. Bounding theory and Greek syntax: Evidence for Wh-movement in NP. Journal of Linguistics 23: 79-108.

Jackendoff, Ray. 1977. X-bar syntax. Cambridge, MA: MIT Press.

Karanastasis, Anastasios. 1974. I fattori che hanno contribuito al regresso dei dialetti neogreci dell'Italia meridionale. Dal dialetto alla lingua, ed. by Manlio Cortelazzo, 5-18. Pisa: Pacini.

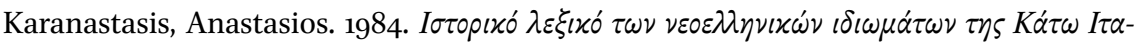
$\lambda i a \varsigma$ ['Historical Lexicon of the Modern Greek Varieties of Southern Italy']. Athens: Academy of Athens. 
Karanastasis, Anastasios. 1992. Origine e sviluppo dei dialetti italogreci. Studi linguistici e filologiciofferti a Girolamo Caracausi, ed. by Giovanni Ruffino, 177-183. Palermo: Centro di Studi Filologici e Linguistici Siciliani.

Katsoyannou, Marianna. 1992a. Voix et conjugaison verbale en gréco. Pour aborder le diasystème. Lectures et perspectives 1: 89-104.

Katsoyannou, Marianna. 1992b. Mort des langues et locuteurs terminaux: le cas de la minorité grécophone de la Calabre, Italie. Plurilinguismes 4: 84-111.

Katsoyannou, Marianna. 1995. Le parler Grico de Gallicianò (Italie): description d'une langue en voie de disparition. Université de Paris $7 \mathrm{PhD}$ Dissertation.

Katsoyannou, Marianna. 1996. Greek in Southern Italy: Morphology of nouns and evolution of the nominal system. Studies in Greek Linguistics 17: 328-341.

Katsoyannou, Marianna. 1997. Interventi simbiotici tra greco e romanzo nell'area linguistica calabrese. In: Atti del $2^{\circ}$ incontro internazionale di lingua greca, ed. by Emanuele Banfi, 513-531. Trento: Università di Trento.

Katsoyannou, Marianna. 1998. Aspects grecs: le cas d'une variété méridionale. Actances 9: 43-62.

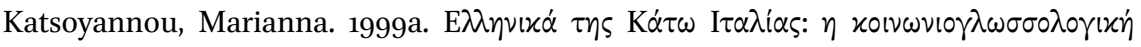
$\dot{\alpha} \pi \circ \psi \eta$ ['Greek of southern Italy: The sociolinguistic perspective']. In: $E \lambda \eta \eta v \iota x \eta$ ' $\Gamma \lambda \omega \sigma-$

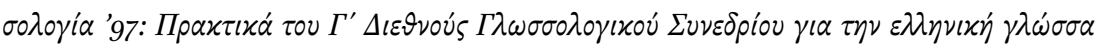
['Greek Linguistics '97: Proceedings of the 3rd International Linguistic Conference

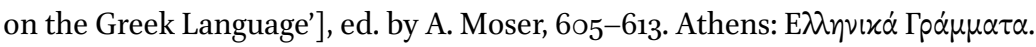

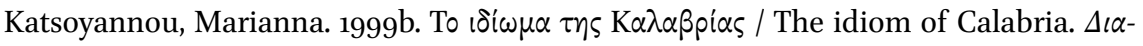

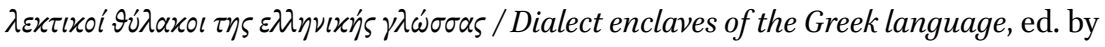

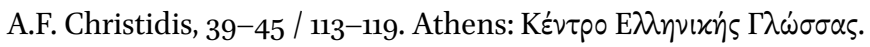

Katsoyannou, Marianna. 2001. Le parler grec de Calabre, situation linguistique et sociolinguistique. Lalies 21: 7-59.

Katsoyannou, Marianna \& Elisabetta Nucera. 1986. Il caso Gallicianò: aspetti sociolinguistici della grecità calabrese. Calabria sconosciuta 5 / 6: 47-51.

Kayne, Richard. 1994. The antisymmetry of syntax. Cambridge: M Iт Press.

Keenan. Edward. 1994. Creating anaphors: An historical study of the English reflexive pronouns. Unpublished Manuscript, University of California at Los Angeles.

Kolliakou, Dimitra. 1999. Non-monotonous anaphora and the syntax of polydefiniteness. In: Empirical issues in formal syntax and semantics, 121-145. The Hague: Thesus.

Kolliakou, Dimitra. 2004. Monadic definites and polydefinites: Their form, meaning and use. Journal of Linguistics 40: $263^{-323}$.

Koopman, Hilda. 2006. Agreement configurations: In defense of "Spec Head". In: Agreement systems, ed. by Cedric Boeckx, 159-199. Amsterdam: John Benjamins.

Kyriakaki, Maria. 2011. DETs in the Functional Syntax of Greek Nominals. University of Toronto PhD Dissertation. 
Laenzlinger, Christopher. 2005. French adjective ordering: Perspectives on D P-internal movement types. Lingua 115: 645-689.

Larson, Richard K. 1998. Events and modification in nominals. In: Proceedings from Semantics and Linguistic Theory (SALT) VIII, ed. by Devon Strolovitch \& Aaron Lawson, 145-168. Ithaca, NY: Cornell University Press.

Larson, Richard K. 1999. Semantics of adjectival modification. Lectures presented at the Lот Winter School. Amsterdam: Lот. [http://semlab5.sbs.sunysb.edu/_rlarson/]

Larson, Richard K. 200oa. ACD in AP? Paper presented at the 19th West Coast Conference on Formal Linguistics (WCCFL 19), Los Angeles. [http://semlab5.sbs.sunysb .edu/rlarson/wccflig.pdf]

Larson, Richard K. 20oob. Temporal modification in nominals. Paper presented at the International Round Table The syntax of tense and aspect. Paris, France (Novem-

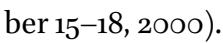

Lausberg, Heinrich. 1939. Die mundarten Suedlukaniens. Halle: Niemeyer.

Ledgeway, Adam. 2007. La posizione dell'aggettivo nella storia del napoletano. Sui dialetti italoromanzi. Saggi in onore di Nigel B. Vincent, ed. by Delia Bentley \& Adam Ledgeway, 104-125. Norfolk: Biddles.

Ledgeway, Adam. 2013. Greek disguised as Romance? The case of Southern Italy. Proceedings of the 5th International Conference on Greek dialects and linguistic theory, ed. by Mark Janse, Brian Joseph, Angela Ralli \& Metin Bagriacik, 184-228. Patras: Laboratory of Modern Greek Dialects, University of Patras.

Lekakou, Marika. 2017. Article doubling. The companion to syntax, ed. by Martin Everaert \& Henk van Riemsdijk, 1-38. Oxford: Blackwell.

Lekakou, Marika \& Christa Szendroi. 2012. Polydefinites in Greek: Ellipsis, close apposition and expletive determiners. Journal of Linguistics 48: 107-149.

Leu, Thomas. 2008. The internal syntax of determiners. NYU: PhD Dissertation.

Longobardi, Giuseppe. 1994. Reference and proper names: A theory of N-movement in syntax and logical form. Linguistic Inquiry 25: 6o9-665.

Longobardi, Giuseppe. 2001. The structure of DPs: Principles, parameters and problems. Handbook of contemporary syntactic theory, ed. by Mark Baltin \& Chris Collins, 652-703. Oxford: Blackwell.

Loporcaro, Michele. 20o9. Profilo linguistico dei dialetti italiani. Bari: Laterza

Maiden, Martin \& Mayr Parry. 1997. The dialects of Italy. London / New York: Routledge.

Mancini, Angelo. 1903. Cantigreci di terra d'Otranto. Lucca: Amedei.

Manolessou, Io. 2000. Greek noun phrase structure: A study in syntactic evolution. University of Cambridge PhD Dissertation.

Manolessou, Io. 2005. The Greek dialects of Southern Italy: An overview. KAMPOS: Cambridge papers in Modern Greek 13: 103-125.

Mansi, F.A. 1937. Da una 'Cronaca Martanese’ (1701-1837). Rinascenza Salentina. Nuova Serie Anno 5, nr. 2. 143-171. 
Manzini, Maria Rita \& Leonardo Savoia. 2018. The morphosyntax of Albanian and Aromanian varieties. Case, Agreement, Complementation. Berlin: De Gruyter.

Marinis, Theodoris \& Phoevos Panagiotidis. 2011. Determiner spreading as DP-predication. Studia Linguistica 65(3): 268-298.

Martino, Paolo. 20og. L'affaire Bovesìa. Un singolare irredentismo. In: Alloglossie e comunità alloglotte nell'Italia contemporanea, ed. by Carlo Consani, Paola Desideri, Francesca Guazzelli \& Carmela Perta, 251-275. Roma: Bulzoni.

Matushansky, Ora. 2002. A beauty of a construction. In: Proceedings of WCCFL 21, ed. by Line Mikkelsen \& Christopher Potts, 264-277. Somerville: Cascadilla Press.

McCloskey, Jim. 2004. Irish nominal syntax 1: Demonstratives. Unpublished Manuscript, University of California, Santa Cruz.

Melissaropoulou, Dimitra. 2012. On the role of language contact in the reorganization of grammar: A case study on two Modern Greek contact induced dialects. Paper presented at the 5th International Conference of Modern Greek Dialects and Linguistic Theory. Ghent, 20-22 September 2012.

Miglietta, Annarita \& Alberto Sobrero. 20o6. Politica linguistica e presenza del grico in Salento oggi. In: Lingue, istituzioni, territori, ed. by Cristina Guardiano, Emilia Calaresu, Augusto Carli \& Cecilia Robustelli, 209-226. Roma: Bulzoni.

Miglietta, Annarita \& Alberto Sobrero. 2007. Spie morfologiche della resistenza del grico in Salento. Rivista Italiana di Dialettologia 31: 19-28.

Milner, Jean Claude. 1978. De la syntaxe de l'interprétation. Paris: Editions du Seuil.

Montinaro, Brizio. 1994. Canti di Pianto e d'Amore dall'Antico Salento. Milano: Bompiani.

Morgante, Lorenza. 2004. La minoranza ellenofona nell'Aspromonte calabrese. Università di Modena e Reggio Emilia Tesi di Laurea.

Morosi, Giuseppe. 1870. Studi sui dialetti greci della terra d'Otranto. Lecce: Editrice Salentina.

Napoli, Donna Jo. 1989. Predication theory: A case study for an Indexing Theory. Cambridge: Cambridge University Press.

Ntelitheos, Dimitrios. 2003. The syntax of emphasis: Split DPs and nominal ellipsis. Proceedings of the 6th International Conference of Greek Linguistics. Department of Philology, University of Crete.

Ntelitheos, Dimitrios. 2004. The syntax of elliptical and discontinuous nominals. University of California at Los Angeles PhD Dissertation.

Orlando, Luigi. 2002. Tesori da Salvare. Canti, riti e tradizioni della Pasqua nella Grecia Salentina. Martano: Grafiche Chiriatti.

Palumbo, Vito D. 1886. Un évangile traduit en gréco-salentin. Paris: Thorin.

Palumbo, Vito D. 1887. Lamento in dialetto calimerese italico. La Cultura Salentina 1/III.

Palumbo, Vito D. 1910. Saggio di un commento dei canti greco-salentini. Martina Franca: Apulia.

Palumbo, Vito D. 1912. Ninne Nanne Grecosalentine. Martina Franca: Apulia. 
Palumbo, Vito D. 1978. Canti Grecanici di Corigliano d'Otranto. Galatina: Congedo.

Panayidou, Fryni. 2013. (In)flexibility in adjective ordering. Queen Mary, University of London PhD Dissertation.

Parlangeli, Oronzo. 196o. Storia linguistica e storia politica nell'Italia meridionale. Firenze: Le Monnier.

Pellegrini, Giovan Battista. 1977. Carta dei dialetti d'Italia. Pisa: Pacini.

Piromalli, Antonio. 1996. La letteratura calabrese. Reggio Calabria: Pellegrini.

Pitrè, Giuseppe. 1872. Dei canti popolari greci nell'Italia meridionale. Palermo: Lauriel.

Profili, Olga. 1983. Le parler grico del Corigliano d'Otranto (province de Lecce, Italie).

Problémes d'interférence entre ce parler grec et les parlers romans environnants, ainsi qu'avec l'italien. Université des langues et lettres, Grenoble, PhD Dissertation.

Profili, Olga. 1985. La romanisation d' un parler grec de l'Italie du Sud par les parlers romans environants. In: Actes du XVIIe Congrès International de linguistique et de philologie romanes, ed. by Dieter Kremer, 129-139. Aix-en-Provence: Université de Provence.

Profili, Olga. 1999. The Greek language in Southern Italy. Dialects enclaves of the Greek language, ed. by Anastasios Phoevos Christidis, 107-112. Athens: Centre for the Greek Language.

Ralli, Angela. 20o6. Syntactic and morpho-syntactic phenomena in Modern Greek dialects: The state of the art. Journal of Greek Linguistics 7: 121-159.

van Riemsdijk, H. 1998. Categorial feature magnetism: The endocentricity and distribution of projections. Journal of Comparative Germanic Linguistics 2: 1-48.

Rohlfs, Gerhard. 1924. Griechen und Romanen in Unteritalien. Genève: L.S. Olschki.

Rohlfs, Gerhard. 1933. Scavi linguistici nella Magna Graecia. Halle: Niemeyer / Roma: Collez. Meridionale.

Rohlfs, Gerhard. 1966. Grammatica storica della lingua italiana e dei suoi dialetti. Torino: Einaudi.

Rohlfs, Gerhard. 1972. Nuoviscavi linguisticinell'antica Magna Graecia. Palermo: Istituto siciliano di studi bizantini e neoellenici.

Rohlfs, Gerhard. 1980. Calabria e Salento. Saggi di storia linguistica (studi e ricerche). Ravenna: Longo.

Rohlfs, Gerhard. 1985. Latinità et ellenismo nel Mezzogiorno d'Italia. Studi e ricerche (dalla Magna Grecia alla Grecia italica). Chiaravalle: Frama Sud.

Romano, Antonio \& Piersaverio Marra. 20o8. Il griko nel terzo millennio: 'speculazioni' su una lingua in agonia. Parabita: Il Laboratorio.

Rouveret, Alain. 1994. Syntaxe du gallois: principes generaux et typologie. Paris: CNRS.

Ruwet, Nicolas. 1982. La Grammaire des insultes et autres etudes. Paris: Editions du Seuil.

Shlonsky, Ur. 2004. The form of Semitic noun phrases. Lingua 114(12): 1465-1526.

Scott, Gary John. 2002. Stacked adjectival modification and the structure of nominal 
phrases. Functional structure in the DP and IP: The cartography of syntactic structures, Volume I, ed. by Guglielmo Cinque, 91-120. Oxford: Oxford University Press.

Sicuro, Salvatore. 1999. İtela na su po' ... Canti popolari della Grecia Salentina da un quaderno (1882-1885) di V.D. Palumbo. Calimera: Ghetonìa.

Smith, Carlota S. 1964. Determiners and relative clauses in a generative grammar of English. Language 40: 37-52.

Sobrero, Alberto \& Maria Teresa Romanello. 1977. Una ricerca sociolinguistica in Salento. Linee d'indagine e primi risultati. In: Aspetti sociolinguistici dell'Italia contemporanea, ed. by Raffaele Simone \& Giulianella Ruggiero, 373-384. Roma: Bulzoni. Spano, Benito. 1965. La grecità bizantina e i suoi riflessi geografici nell'Italia meridionale e insulare. Pisa: Libreria Goliardica.

Sproat, Richard \& Chilin Shih. 1988. Prenominal adjectival ordering in English and Mandarin. Proceedings of NELS 12: 465-489.

Sproat, Richard \& Chilin Shih. 1991. The crosslinguistic distribution of adjective ordering restrictions. Interdisciplinary approaches to language, ed. by Carol Georgopoulos \& Roberta Ishihara, 565-593. Dordrecht: Kluwer.

Squillaci, Maria Olimpia. 2017. When Greek meets Romance: A morphosyntactic analysis of language contact in Aspromonte. University of Cambridge PhD Dissertation.

Stavrou, Melita. 2012. Postnominal adjectives in Greek indefinite noun phrases. Functional heads, ed. by Laura Brugé, Anna Cardinaletti, Giuliana Giusti, Nicola Munaro \& Cecilia Poletto, 379-394. New York: Oxford University Press.

Stavrou, Melita. 2013. The fine(r) ingredients of adjectival modification in Greek: The Romance connection. Paper presented at IG G 39, Modena and Reggio Emilia, February $21-23,2013$.

Stavrou, Melita \& Geoffrey Horrocks. 1989. Clitics and demonstratives within the DP. Studies in Greek Linguistics 19: 225-245.

Stomeo, Paolo. 1980. Racconti Greci Inediti di Sternatia. Lecce: La Nuova Ellade.

Tommasi, Salvatore. 1998. Io' Mia Forá ... Fiabe e racconti della Grecia Salentina dai quaderni (1883-1912) di Vito Domenico Palumbo. Calimera: Ghetonìa.

Toso, Fiorenzo. 2008. Le minoranze linguistiche in Italia. Bologna: Il Mulino.

Troiano, Rosa. 1982. Le comunità etnico-linguistiche in Calabria. Calabria Sconosciuta VI/22-2. 49-52.

Trovato, Salvatore C. 1981. Considerazioni sul lessico dei dialetti galloitalici della Sicilia. In: Etimologia e lessico dialettale, 581-596. Pisa: Pacini.

Trovato, Salvatore C. 1989. La “Lombardia siciliana”. Tavole a cura di Salvatore C. Trovato. Progetto Galloitalici: Saggi e Materiali 1, offerti a Giovanni Tropea, ed. by Salvatore C. Trovato, 21-23. Catania: Dipartimento di Scienze linguistiche filologiche e letterarie medievali e moderne, Università di Catania.

Tsakali, Vina. 2008. Similarities in the interpretation of doubling constructions. Paper presented at the 29th Meeting of the Department of Linguistics of the Aristotle University of Thessaloniki. 
Valois, Daniel. 1991a. The internal syntax of DPs. University of California at Los Angeles PhD Dissertation.

Valois, Daniel. 1991b. The internal syntax of DP and adjective placement in French and English. Proceedings of NELS 21, 367-382.

Velegrakis, Nikolaos. 2011. The syntax of Greek polydefinites. University College London PhD Dissertation.

Villalba, Xavier. 2007. True and spurious articles in Germanic and Romance. Cuadernos de Linguistica del I.U.I. Ortega y Gasset 14: 121-134.

Vişan, Ruxandra. 2003. Characterizing N de N Qualitative Constructions in Romanian. Bucharest Working Papers in Linguistics 5: 137-148.

Vişan, Ruxandra. 2006. The N1 of N2 Construction. Unpublished Manuscript, University of Bucharest.

Wallace, Daniel B. 1996. Greek grammar beyond the basics. An exegetical syntax of the New Testament. Grand Rapids, MI: Zondervan. 